
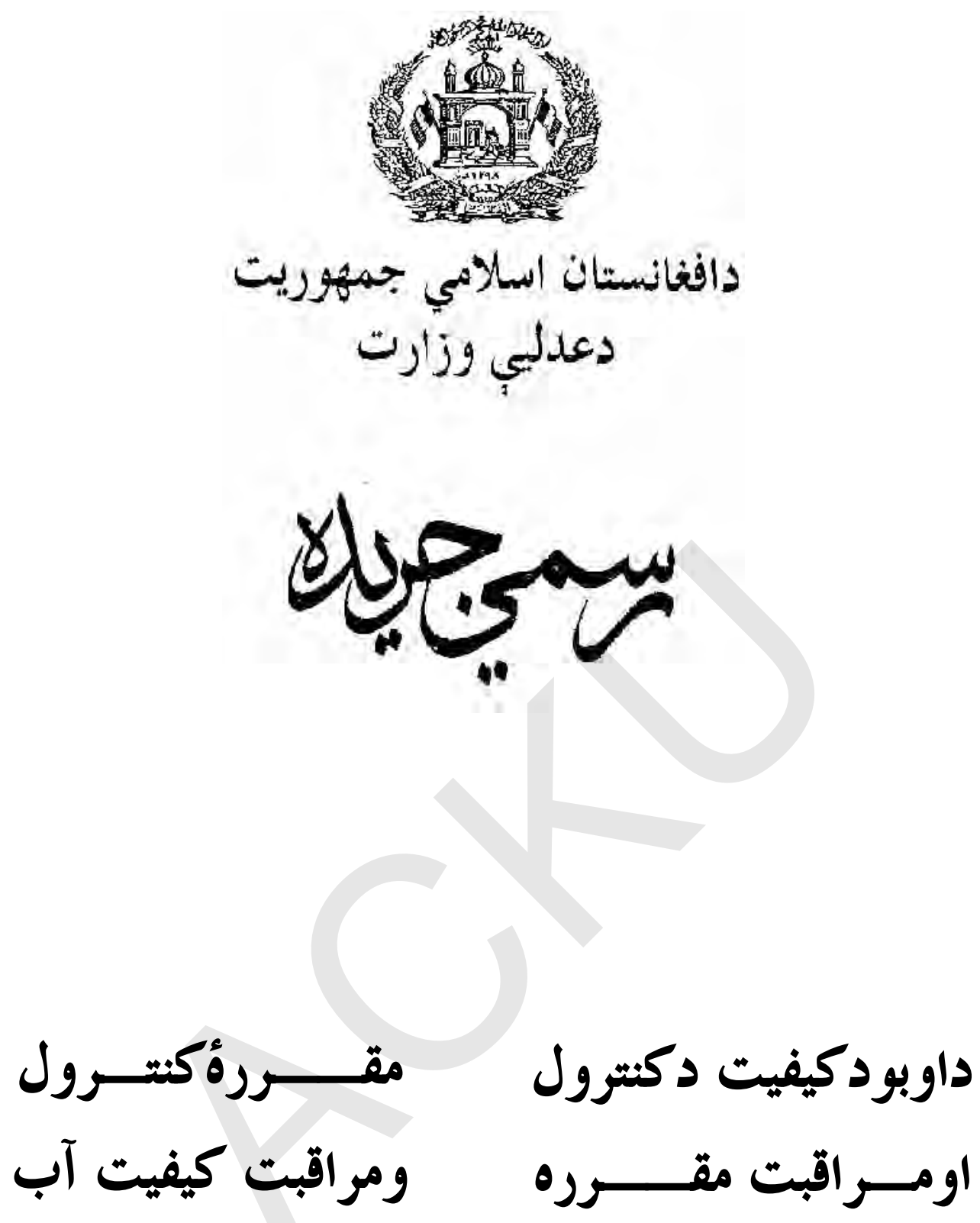

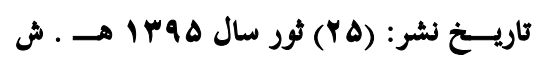

$$
\begin{aligned}
& \text { نمبر مسلسل: (Y) (Y) }
\end{aligned}
$$

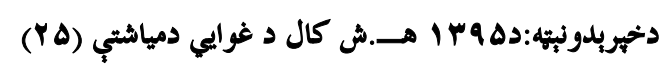

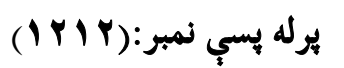




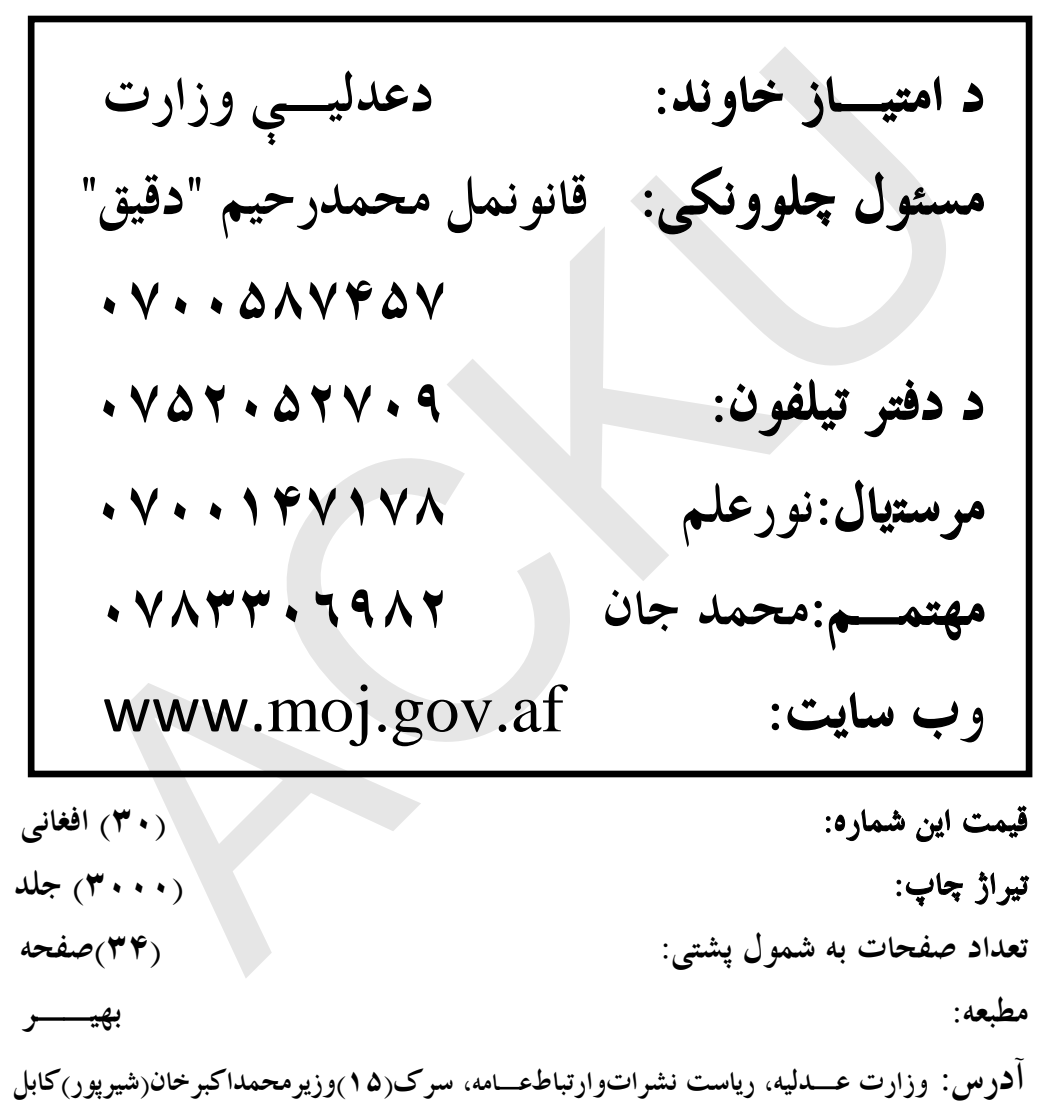


حكم

رئيس جمهورى اسلامى افغانستان

درمورد انفاذ مقررة

كنترول و مراقبت

كيفيت آب

شماره: (YVYV)

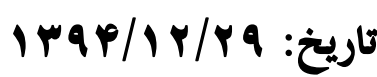

به وزارت محترم عدليها

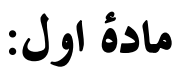

مقررة كنترول و مراقبت كيفيت آب

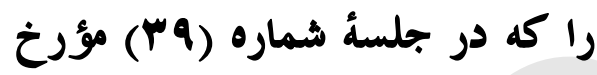

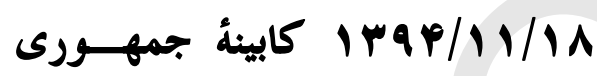

اسلامى افغانستان به داخل (\$) فصل

و (YV) ماده تصويب گرديده است،

$$
\text { منظور مى دارم. }
$$

مادةُ دوم: منطو دار

اين حكم همراه با مصـــوبة كابينــه

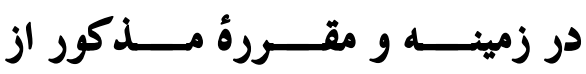

تاريخ نشر در جريدة رسمى، نافــــ

است.

$$
\text { محمد اشرف غنى }
$$

رئيس جمهورى اسلامى افغانستان
د اوبو د كيفيت د كنترول او مراقبت

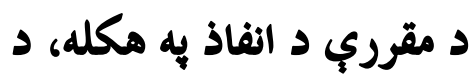

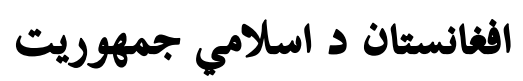

د رئيس

حكم

كنه: (YVYV)

نجيته:

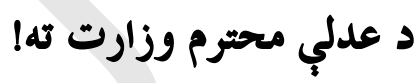

$$
\text { لومرى ماده: }
$$

د اوبو د كيفيت د كنترول او مراقبت

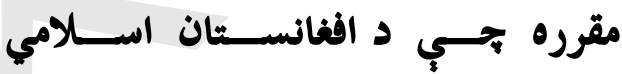

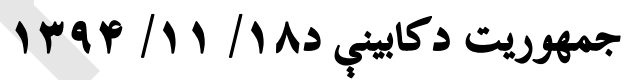

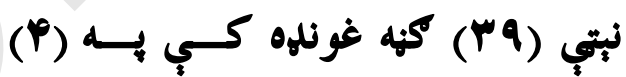

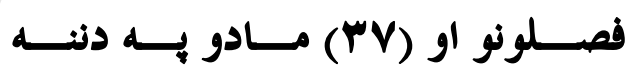
كي تصويب شوي ده، منظوروم. دوه يمه ماده:

دغه حكم به دي برخه كي د كابيني له

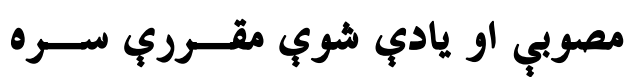
يوحاى، به رسمي جريده كي د خيربدو

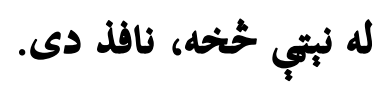
محمد اشرف غني

دافغانستان داسلامي جمهوريت رئيس 


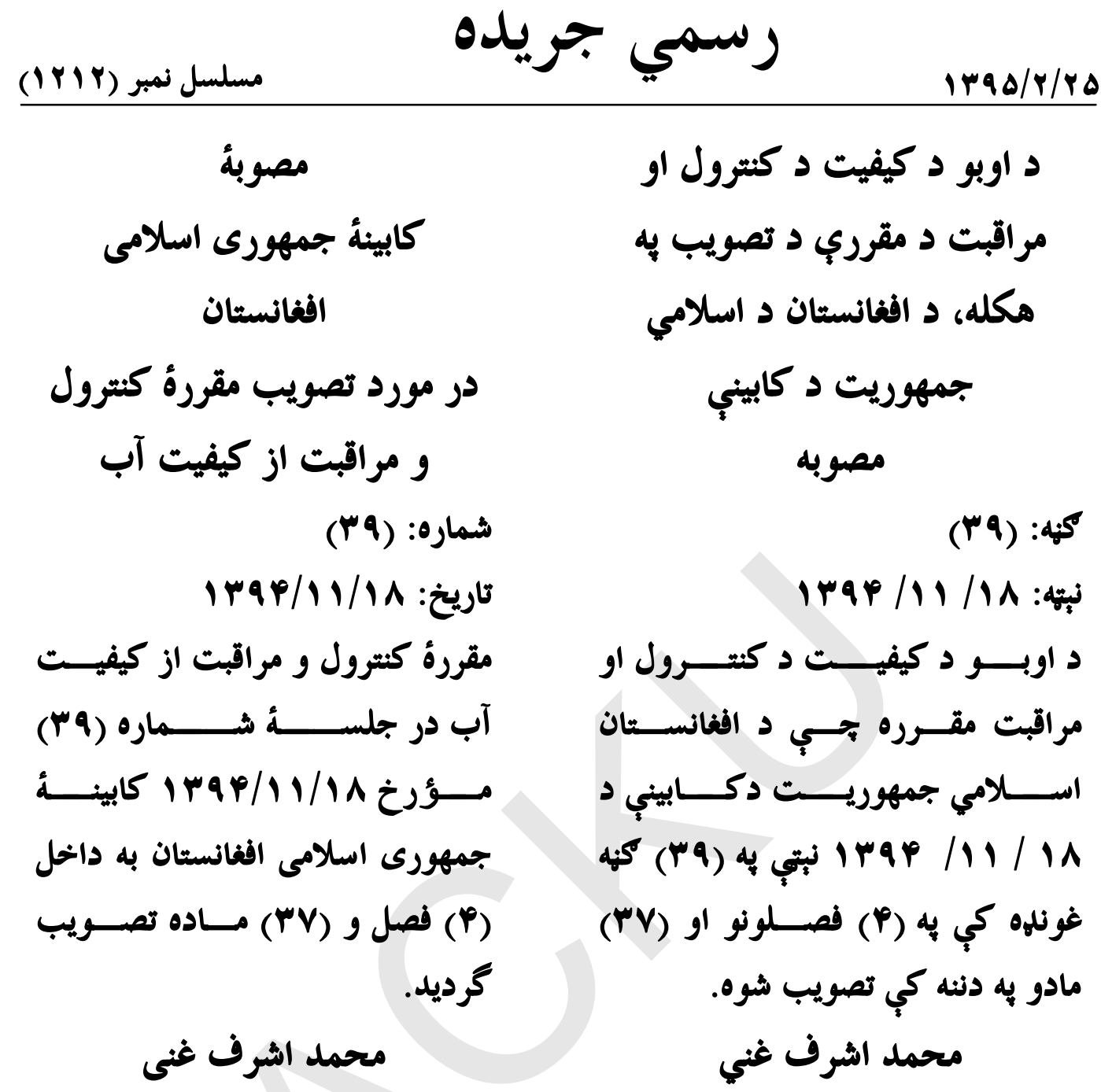

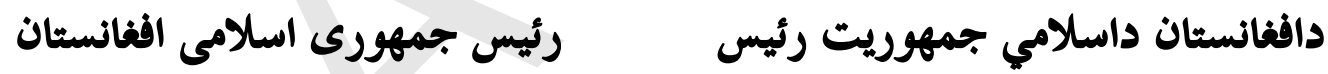




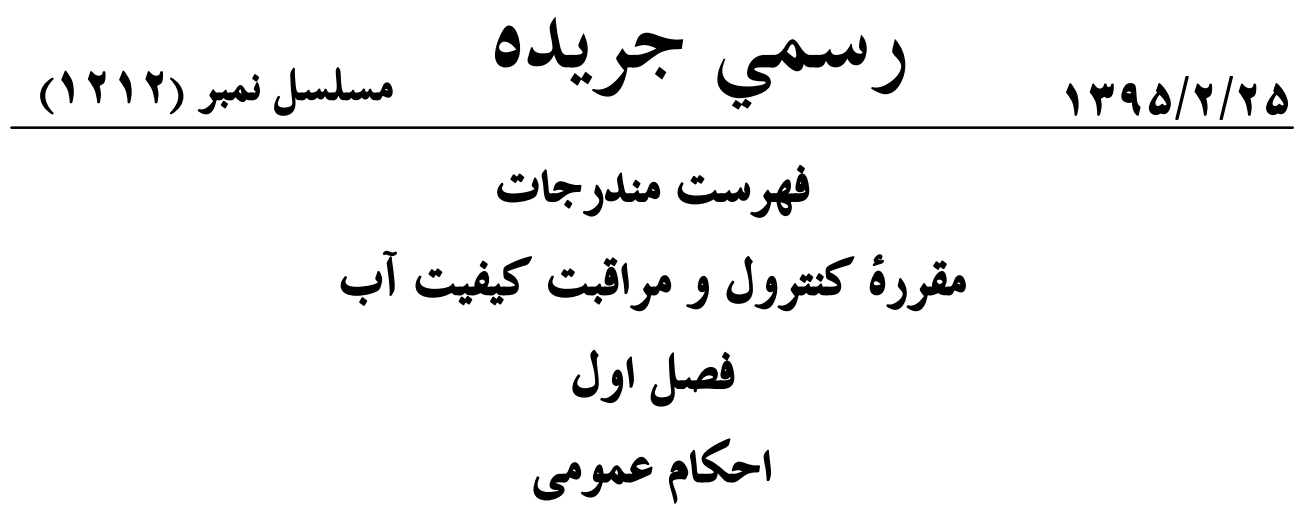

\begin{tabular}{|c|c|}
\hline صفحه & عنو ان \\
\hline $7 .$. & مبنى \\
\hline $7 \ldots$ & اهد \\
\hline V... & اصط \\
\hline
\end{tabular}

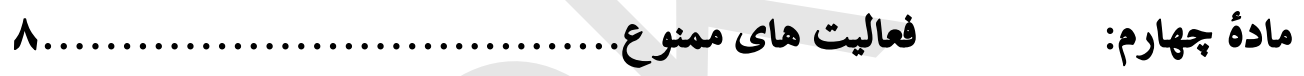

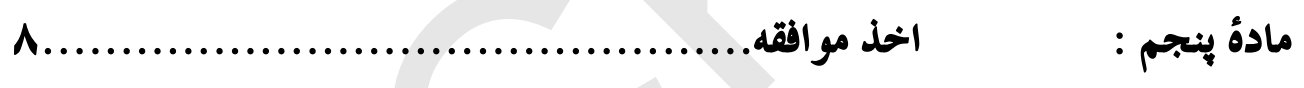
فصل سوم

مكلفيت وزارت ها و ادارات دولتى و مراجع غير دولثى و اشخاص موم

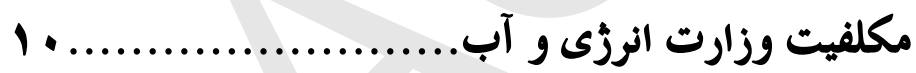

مادة ششم : مادمُ

مكلفيت وزارت زراعت، آبيارى و مالدارى...............

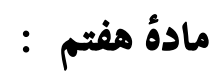

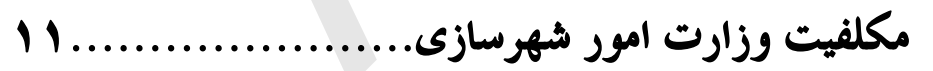

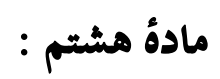

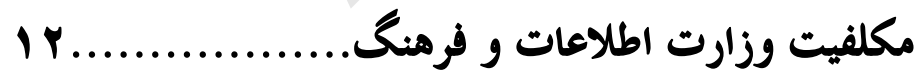

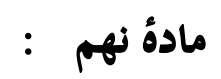

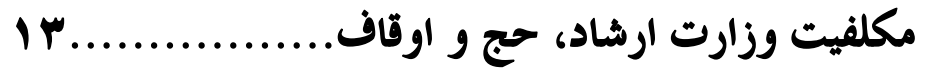

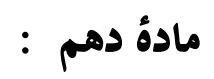

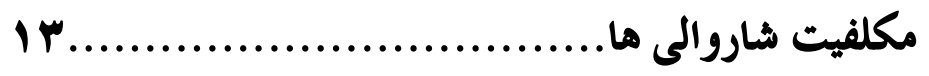

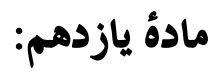




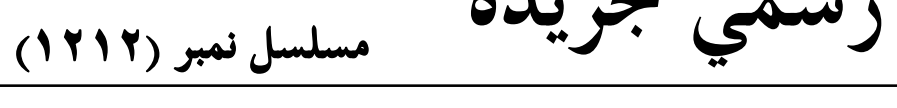
$1 r q \Delta / r / r \Delta$

مكلفيت شركت آب رسانى و كاناليزاسيون شهرى. مادة دوازدمم:

ip افغان...

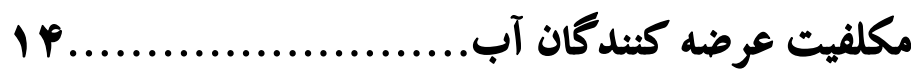

مكلفيت وزارت احياء و انكشاف دهات................

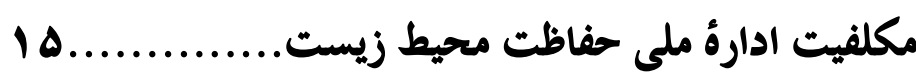

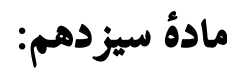

مكلفيت ادارة ملى ستندرد..................................

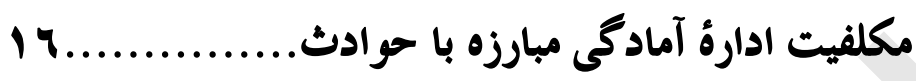

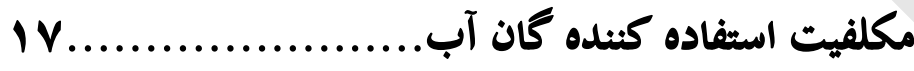

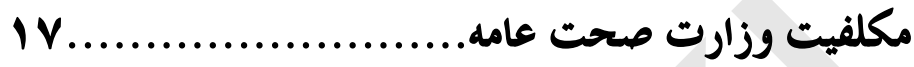

مكلفيت ادارة راديوتلويزيون ملى.......................... مادة جهاردمم: - مادة

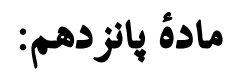

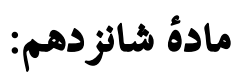

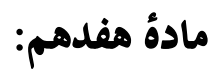

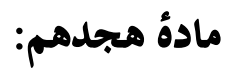

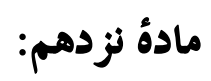

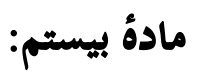

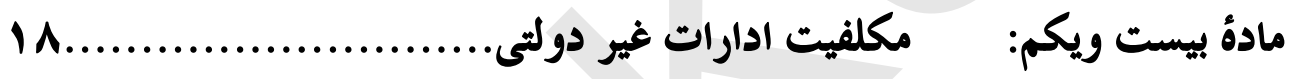

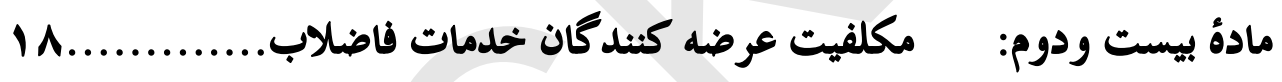

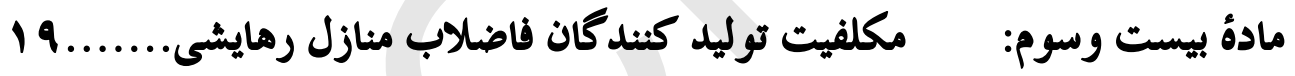

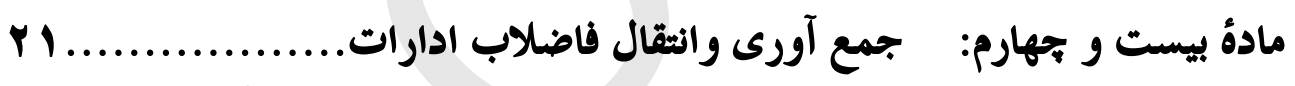

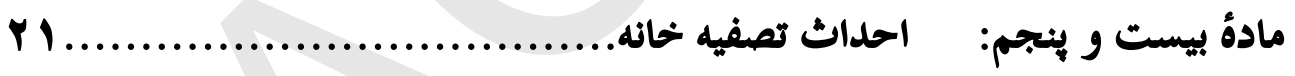

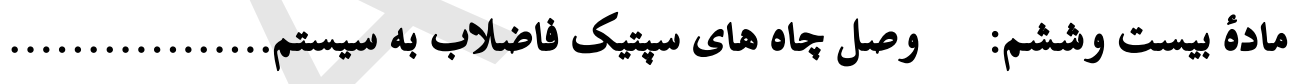

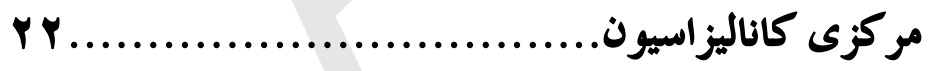

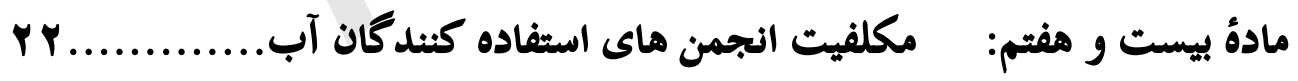

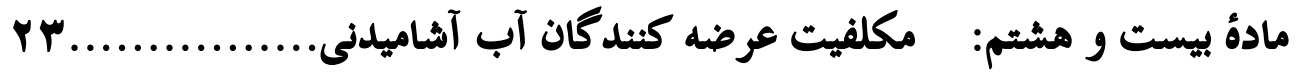

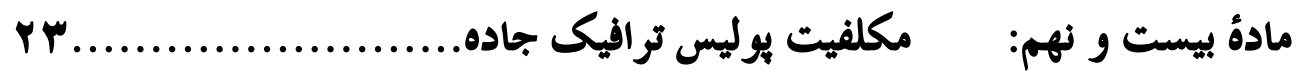




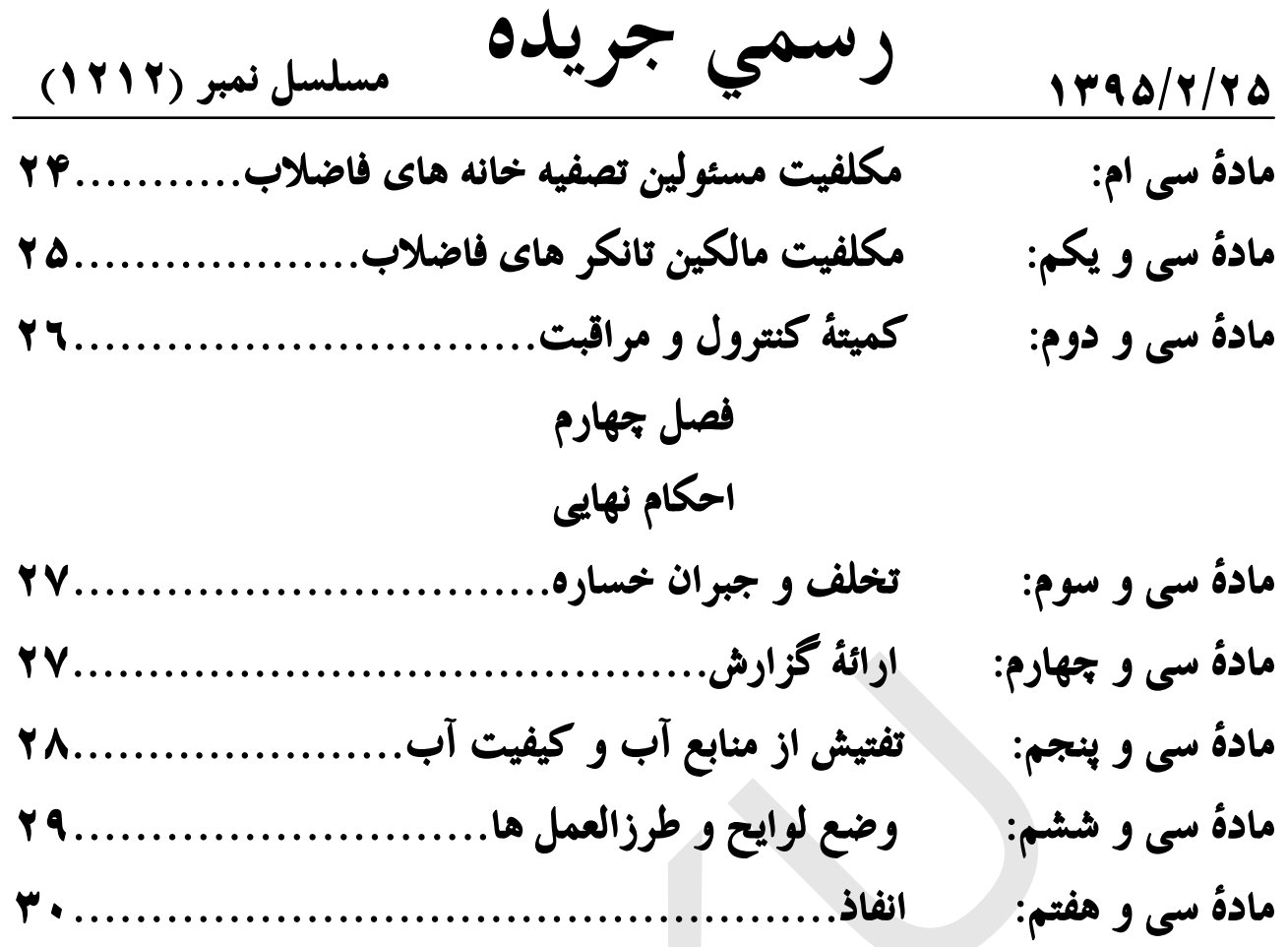


رسمي جريله

$\mid r q \Delta / r / r \Delta$

مقررة كنترول و مراقبت

د اوبو دكيفيت دكنترول او

كيفيت آب

فصل اول

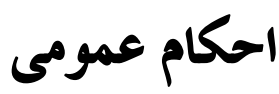

مراقبت مقرره

لومي فصل

عمومي حكمونه

$$
\text { مادة اول: مبنى }
$$

اين مقــره بــه تأسـى از احكـــام

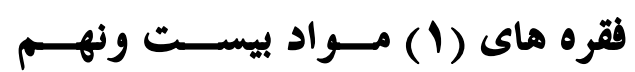

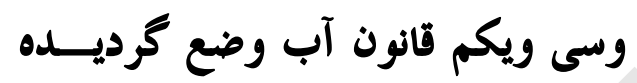
است.

$$
\text { مادة دوم: المداف: }
$$

اهداف اين مقرره عبارت اند از:

1- تنظيم امورمربــوط بــــ تعيـين

معياركيفيت آب.

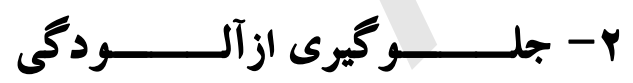

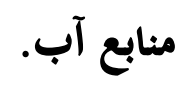

r- كنترول معيــار كيفيــت منسـابع

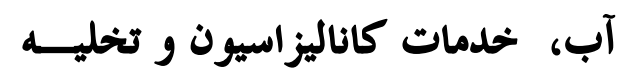

فاضلاب.
لومبني ماده:

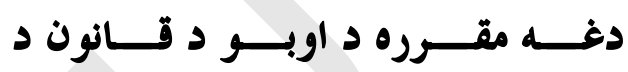

نها ويشتمي او يوديرشمي مادو به (1) فقرو كي ددرج شور حكمونو له مخي، وضع شوي ده.

موخي دوه يمه ماده:

ددي مقرري موخي عبارت دي له: 1- د اوبو دكيفيت د معيار به تــاكلو دوري

يوري د اروندو جارو تنظيم.

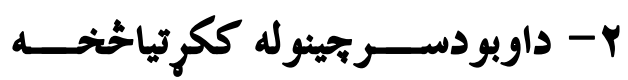
مخنيوى. ץ- د اوبو د سرجينو د كيفيت د معيار

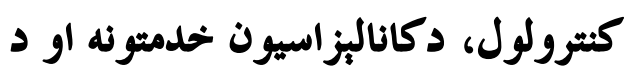
فاضلآب (ناياكواوبو) تخليه. 


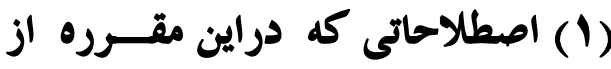

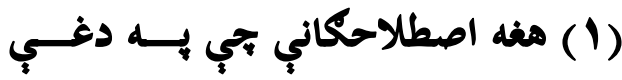
آن تذكر بعمل آمده ممــان مفــاهيم مقرره كي ذكرشوي دي، هماغه د اوبو مندرج مادة سوم قانون آب را افــاده د قانون به دربيمه ماده كي درج شوي دمي دمي

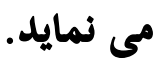
مفاهيم افاده كوي.

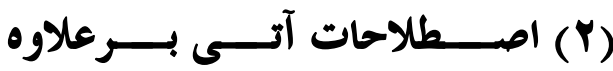
اصطلاحات مندرج فقرة (1) اين ماده مفاهيم ذيل را افاده مى نمايد:

$$
\text { 1- فاضلاب: }
$$

آبهاى مستعمل است كه از مصــارف هغه مستعملي اوبه دي بجي د معيشــي معيشتى، بدرفت ها، وكارخحانه هــاى كلكبتونو، بدرفتونو، صنعتي كارخانو،

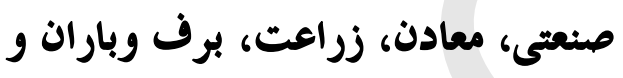
كانونو، زراعت، واوري اوباران اوزابر آب هاى زابر به وجود آمــده ومــــواد معاد

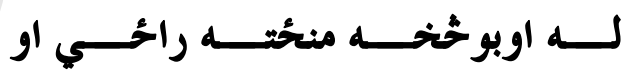

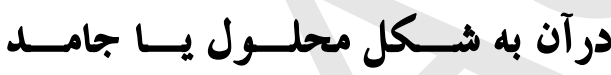
مواد بكي د محلول ياجامد به ثـــكل مى باشد.

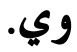

$$
\text { r - تخليه: }
$$

$$
\text { r - تخليه: }
$$

رها كـــرن، دوركــــدن، در محســل يربنبودل، ليري كول، ير حُاى كـــول

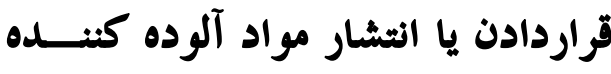

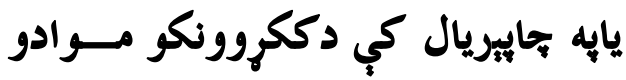
درمحيط بوده كه طور مستقيم يا غير

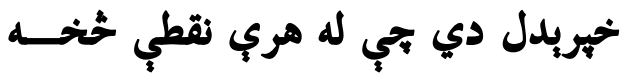

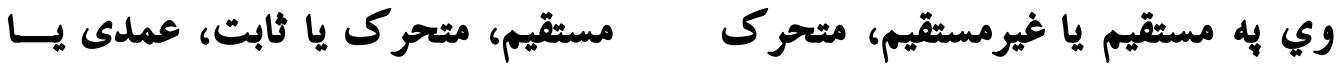

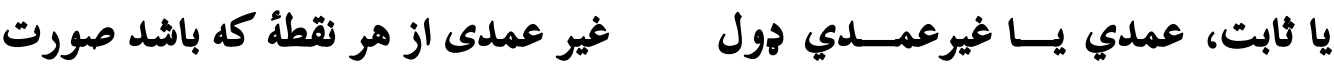


ر سهمي جريله

$$
\begin{aligned}
& \text { مى گيرد. } \\
& \text { ץ- آب آشاميدنى: } \\
& \text { ب- دمخبناك اوبه: }
\end{aligned}
$$

آبى اسـت كه خصوصيت فزيكسى ابكي،

مغه اوبه دي جي فزيكي، بيولوزيكي او اوني بيولوزيكى و راديواكتيفى آن درحدى آنى باشد كه مصرف ونوشيدن آن دركورتاه مدت يا درازمدت برصحت انسيسان تأثيرات سوء نداشته باشد.

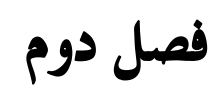

فعاليت هاى آلوده كنيدة منابع آب آب

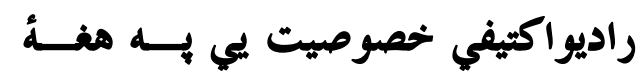

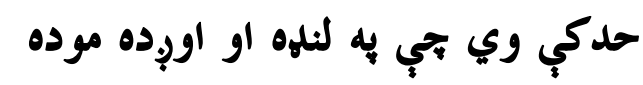

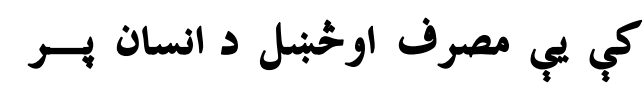
روغتيا ناوره اغيزي ونلري. دوه يم فصل فادة جهاريت هاى ممنوع: فعاليت هاى كه باعث آلودخى منسابع آب بيش از حد مجاز مغاير ستندردهاى

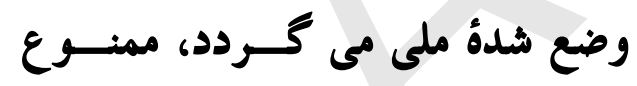
مى باشد. مادة بنجم: اخذم موافقه (1) وزارت ها وادارات دولتى مكلف اند، قبل از صدور جوازنامه واجازه نامه فعاليت ماى ذيل، موافقه كتبـى ادارة

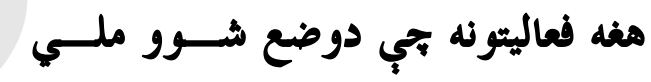

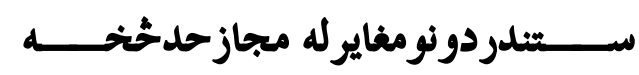
زيات د اوبو د سرجينو دككرتيا باعث كرئ، منغ دي. بنحمَه ماده:

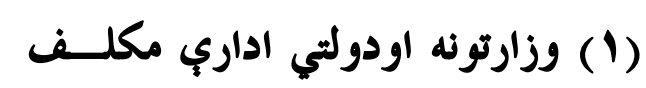

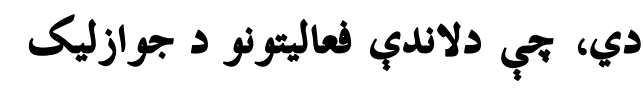

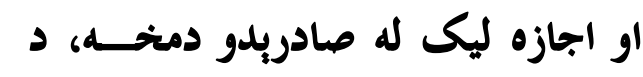




\section{رسهي جريله}

$1 Y Q \Delta / Y / r \Delta$

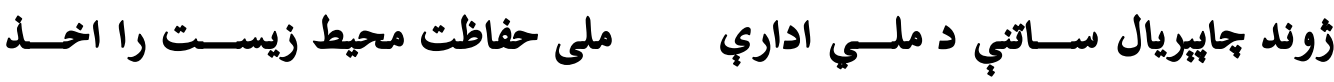

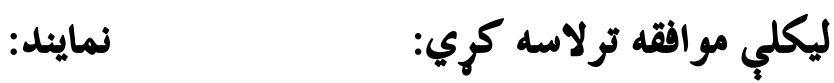

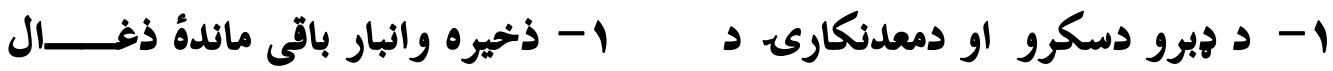

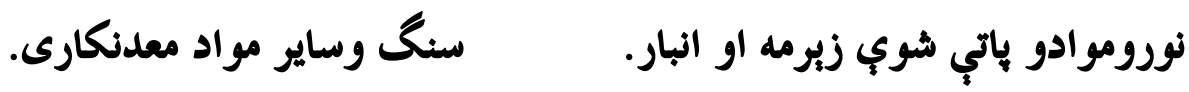

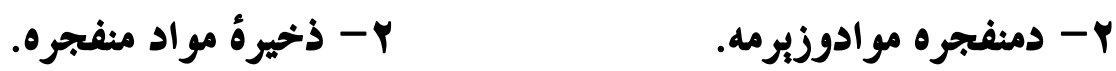

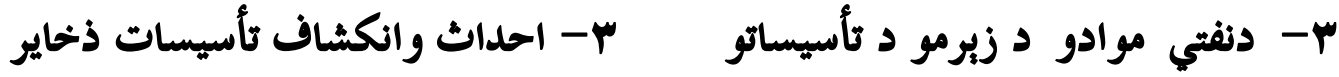

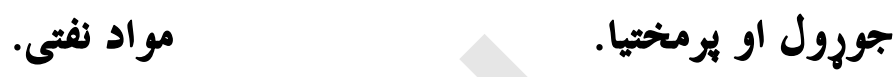

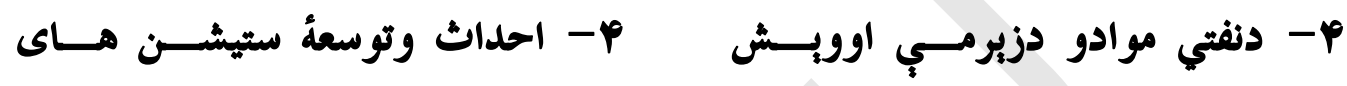

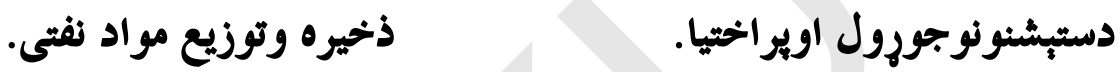

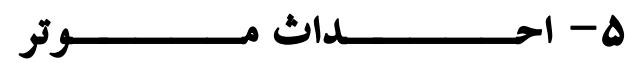

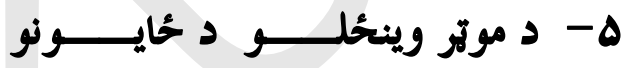

(موترشوييو) جورول.

צ- انبار وسايط تخريب شده، تايرهاى

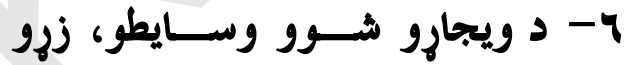

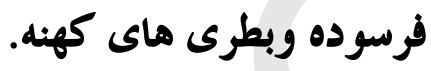

تايرونو او زرو بطريو انبارول.

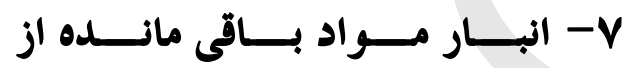

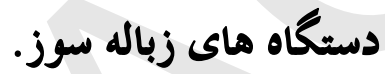

ه- احداث جـــاه مــاى فاضـلاب

سيتيك.

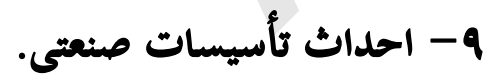

• 1- احداث فارم هـاى مالــدارى

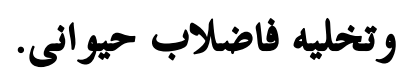

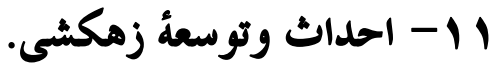

- V- له زباله سوزو دستكاور شخخه دياتي

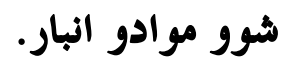

1- دفاضلآب سـيتيك خــاه كسانو

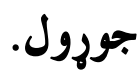

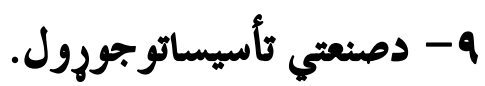

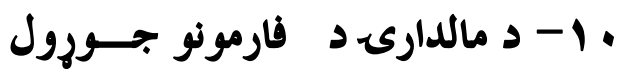
او داويواني فاضلآب تخليه.

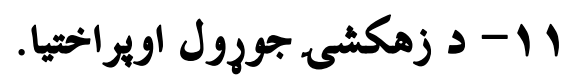

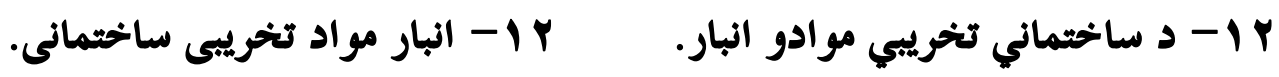

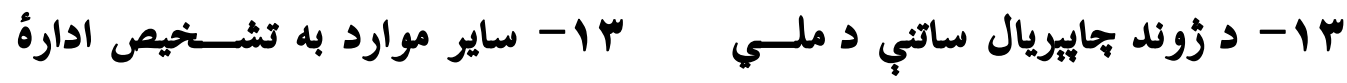




\section{رسهي جريده}

$\mid r q \Delta / r / r \Delta$

ملى حفاظت محيط زيست.

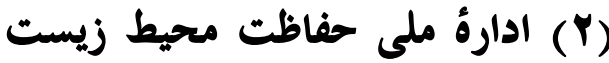

مكلف است، فعاليت ماى مندرج فقرة

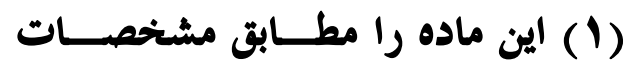

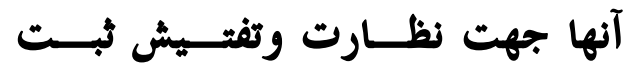

نمايد.

فصل سوم

مكلفيت وزارت ها وادارات

دولتى و مراجع غير دولتى و

اشخاص

$$
\text { مكلفيت وزارت انرزى وآب }
$$

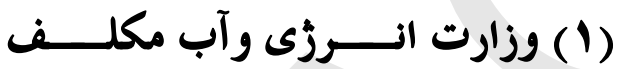

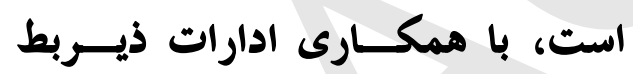
سكتور آب، نقشه ها ى احتمالى آسيب آداري

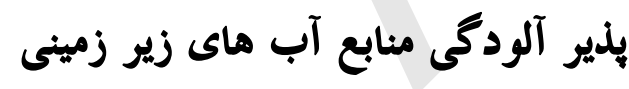
را تهيه واز كيفيت منابع آب هاى زير آنيا زمينى به صــورت متـــداوم كنتــرول ومراقبت نمايد.

(ז) وزارت انرزى وآب مكلف است، با ممكارى ادارات ذيربط سكتور آب
اداري به تشخيص نورموارد.

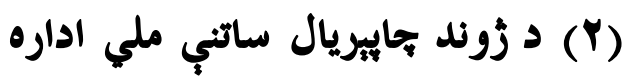
مكلفه ده، ددي مادي به (1) فقره كي كي درج شوي فعاليونه دهغود مشخصاتو

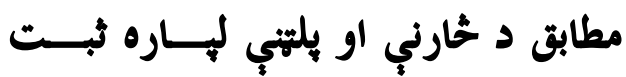
كري. درييم فصل

دوزارتونو او دولتي ادارو او نادولتي مراجعو او الشخاصو مكلفيت

د انرزى او اوبو وزارت مكلفيت

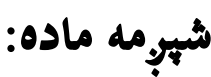
(1) د انرزى او اوبو وزارت مكلــف دورد دي، د اوبو دسكتور د اروندو ادارو بـ داريه

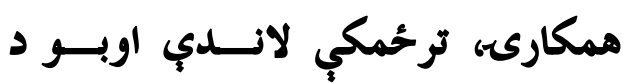

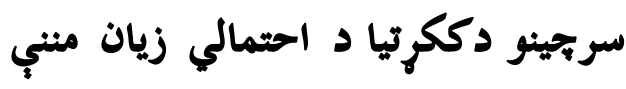
نقشي برابري او ترخمكي لاندي اوبو د دئ سرجينو له كيفيت شخخه به متلداوم هول سره كنترول اوخارنه وكري.

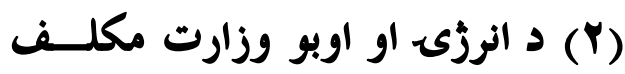

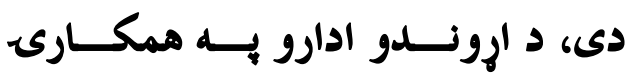




\section{رسمي جريده}

$\mid r q \Delta / r / r \Delta$

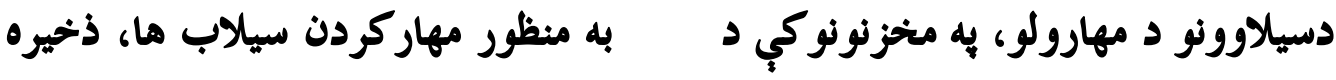

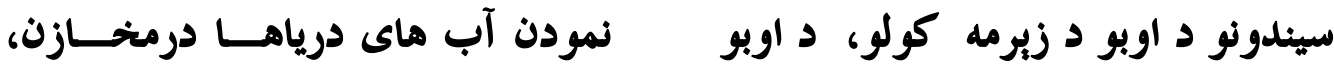

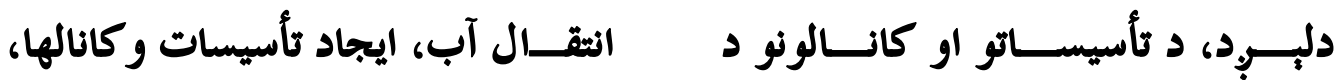

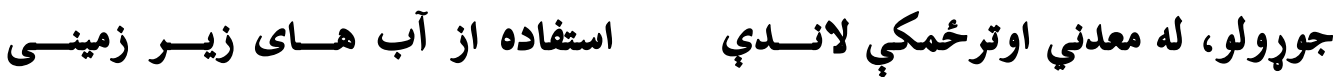

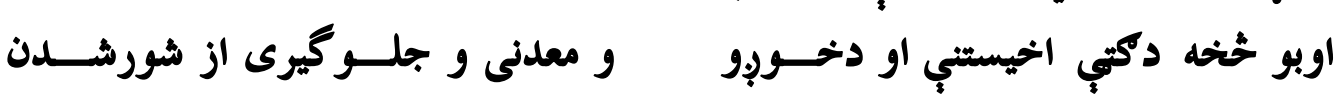

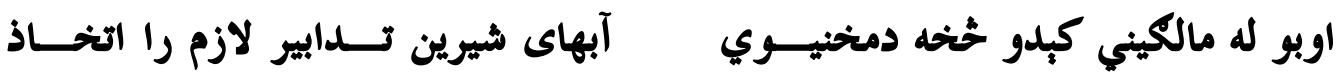

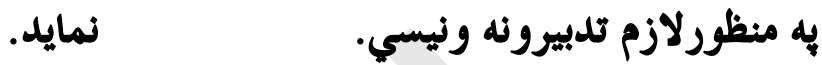

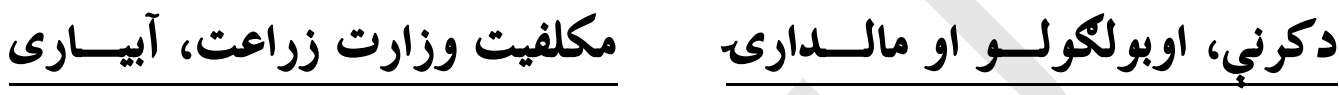
مادة هفتم: ومالدارى وزارت مكلفيت

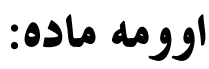

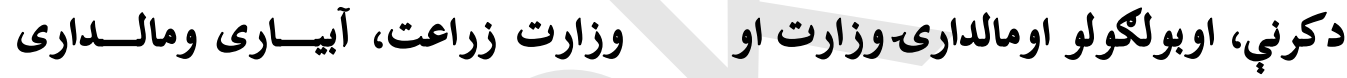

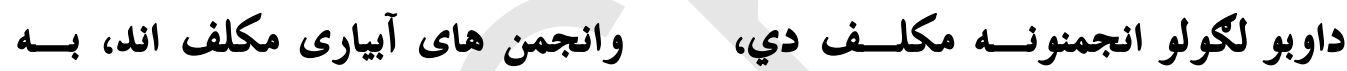

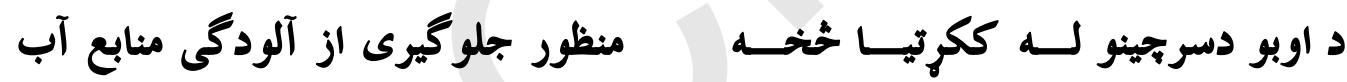

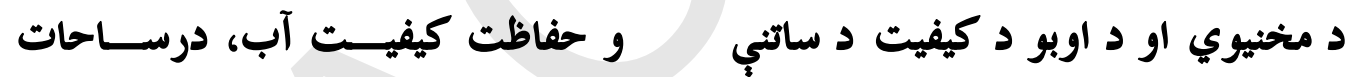

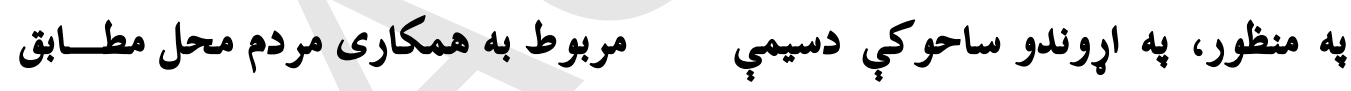

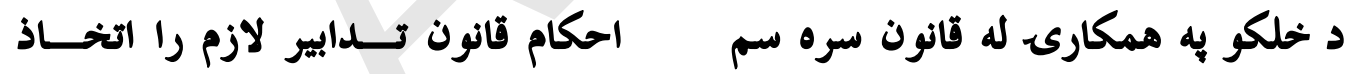

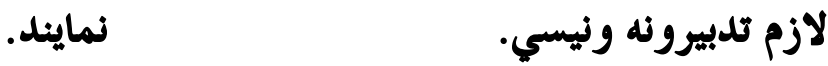
مكلفيت

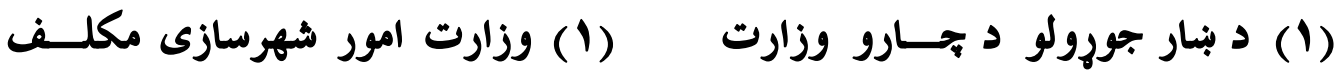

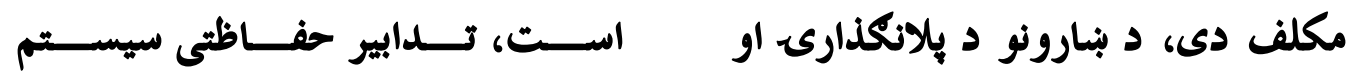




\section{مسلسل نمبر (I M Y \\ رسهي جريله}

كاناليزاسيون و تصــفيه خحانــهـ را بـــا

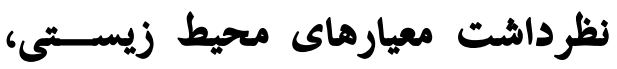

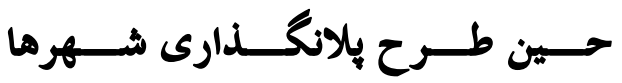

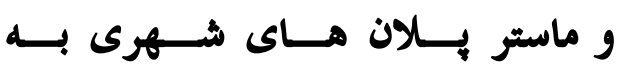

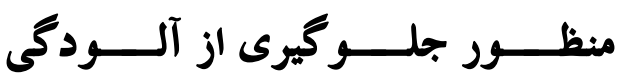
منابع آب وحفاظت كيفيت آب رعايت نمايد.

(Y) وزارت امور شهرسازى نمى تواند،

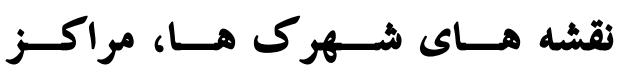
تجارتى وصنعتى را بدون موجوديــت تصفيه نحانه فاضلاب بــا نظرداشــــت

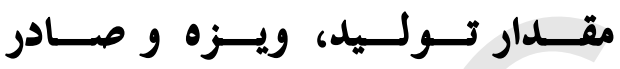
نمايد.

مكلفيـــــــت وزارت اطلاعـــــــات

$$
\text { مادهُ نهم: منرك }
$$

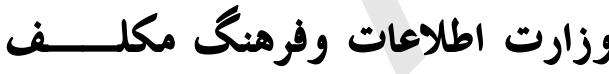

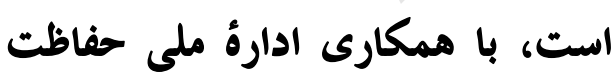
محيط زيست وادارات ذيربط سكتور

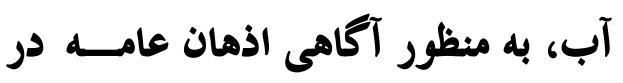
مورد اهميت آب و اضرار آلودكى آنى آن مادمان

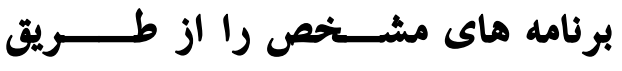

بناري ماستر هلانونو د طرح به وخــت كــي د اوبـــو د ســـرجينو دككرتيــا د مخنيوي او د اوبو دكيفيت د ساتني

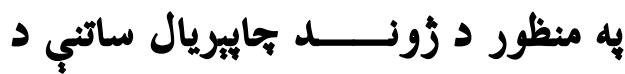
معيارونويه يام كي نيولوسره دتصــفيه خانو اوكاناليزاسيون دسيستم حفاظتي تلدبيرونه به بام كي ونيسي.

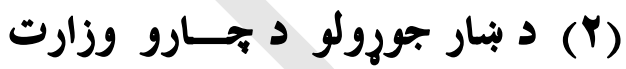
نشي كولى، د توليد اندازي ته به هـــام سره د تصفيه خحانو او فاضلآب له شتون يوته د بنار كوتو، سوداكريزو او صنعتي

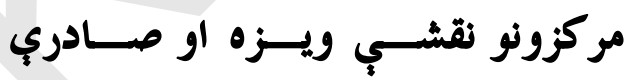
كري. د اطلاعاتـــو او فرهنــك وزارت مكلفيت داطلاعاتواو فرهنك وزارت مكلــف دى، د زوند د جاييريال ساتني د ملــي

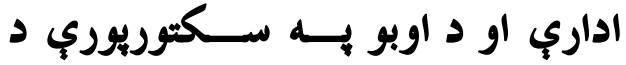

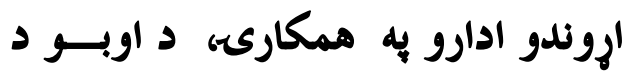

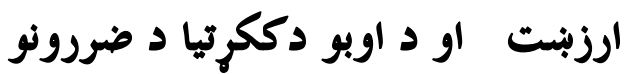
به اره د عامه اذهانو ديوهاوي به منظور 


\section{مسلسل نمبر (IYTY) \\ رسهي جريله}

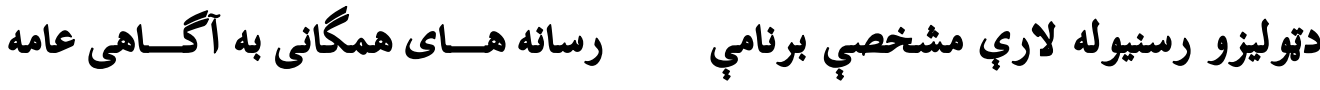

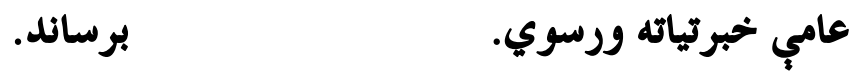

مارسمادي

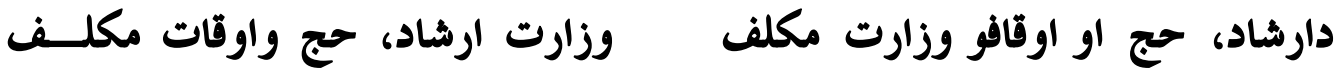

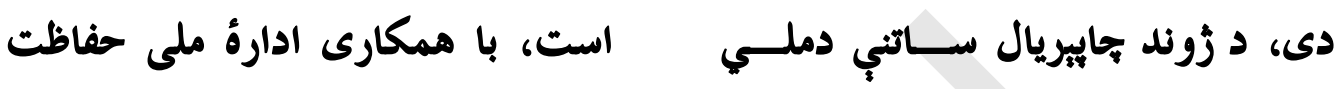

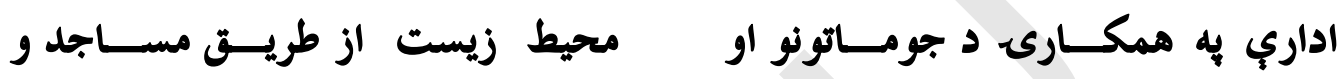

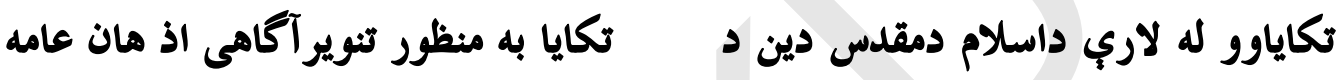

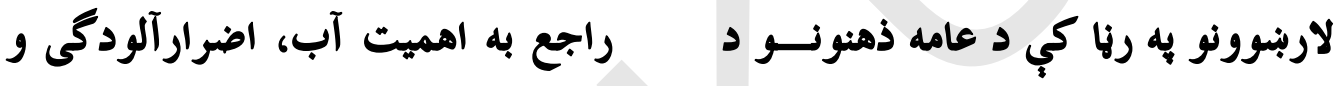

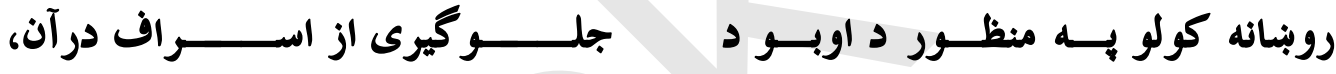

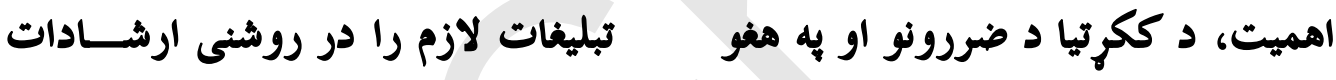

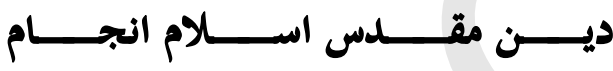

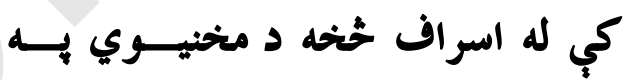
دمد. مكله، لازم تبليغات وكري.

\section{مكلفيت شاروالى ها

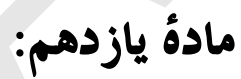
شاروالى ما مكلف اند، انتقال وتخلــيه

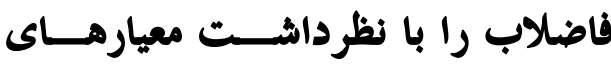

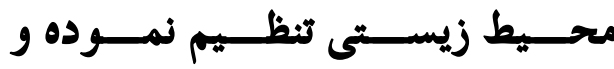

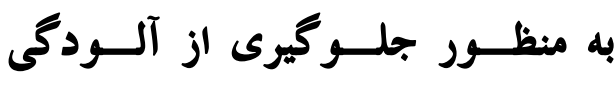

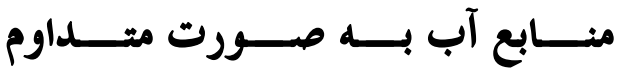

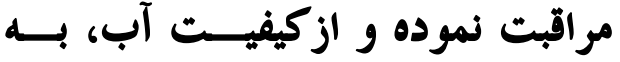

$$
\text { يوبنارواليومكلفيت لونهات }
$$

بناروالى كاني مكلفي دي، د فاضلآب

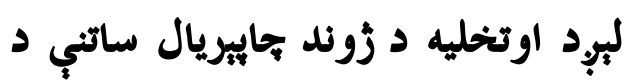

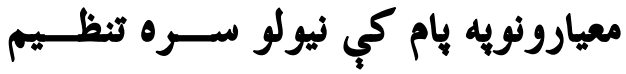
كري او د اوبو د سرجينو دككيديدو د دئر مخنيوي به منظور بــهـ متــــاوم هول دئل

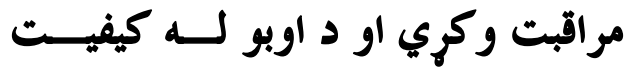




\section{مسلسل نمبر (IY) \\ رسهي جريله \\ $\mid r q \Delta / r / r \Delta$}

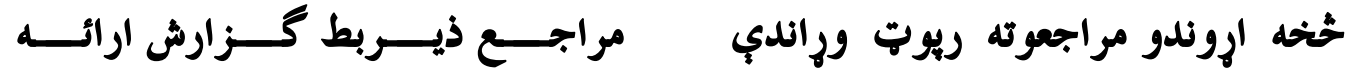

كري.

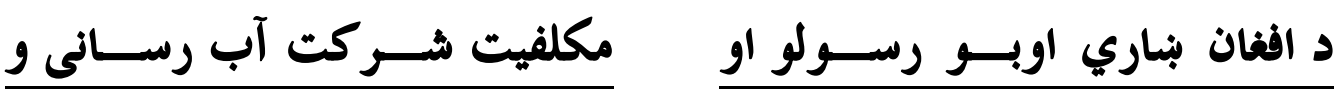
دوالسمه ماده:

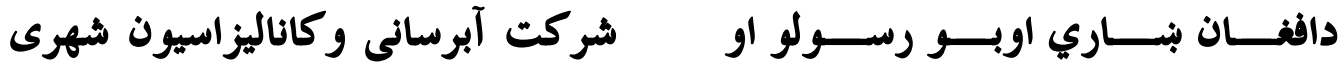

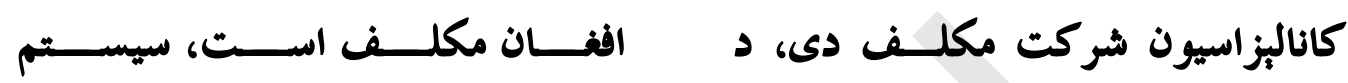

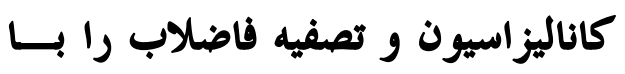

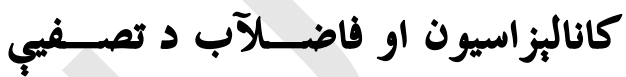

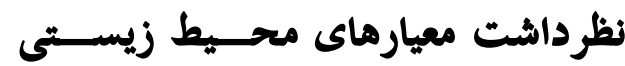

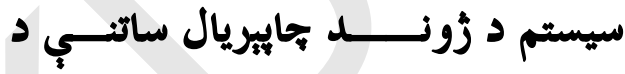
نظارت نموده و طبق اساسنامه مربوط،

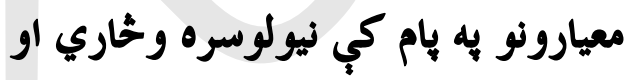

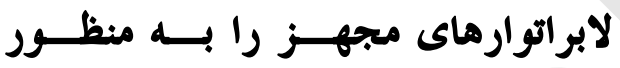
تشـخيص كيفيـت آب آثــاميدنى له إوندي اساسنامي سره سم د دخبنلو اوبو د كيفيت د تشخيص او د فاضلآب

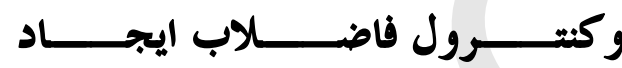
نمايد. دكترول به منظور مجهز لابراتوارونسه. مكلفيت عرضه كند مادان آب

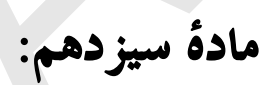

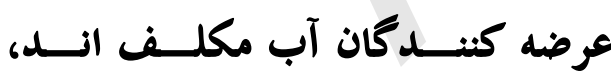

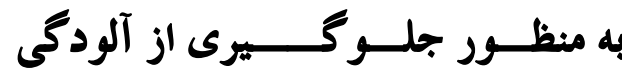

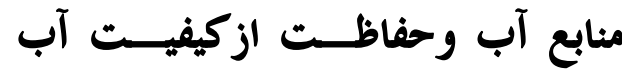
درســاحات مربــوط تــــابير لازم را

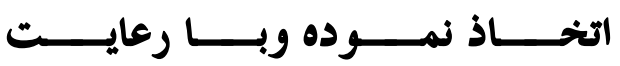
معيارهاى محيط زيســى از هــرايط

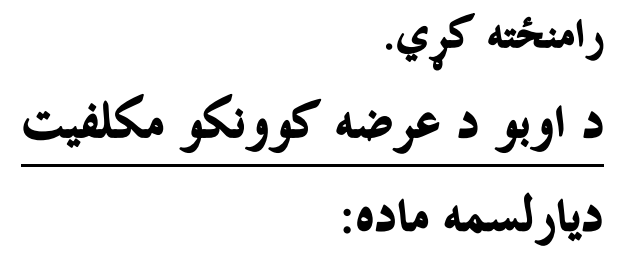

د اوبو عرضه كوونكي مكلف دي، به ديه

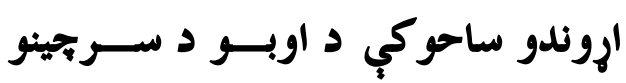

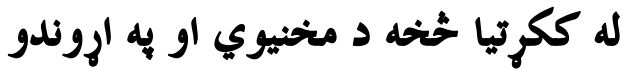

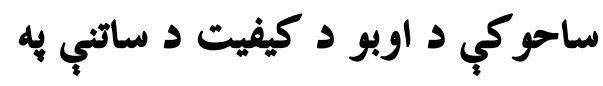

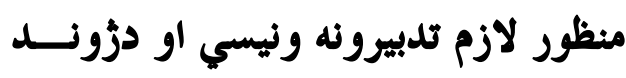
جاييريال د معيارونو به رعايتولو سـره لهره 


\section{مسلسل نمبر (I Y Y (1) \\ رسهي جريله}

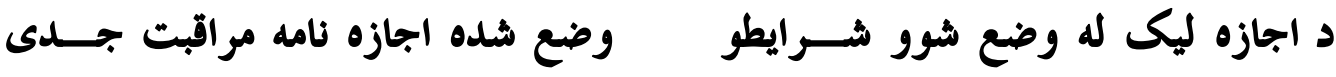

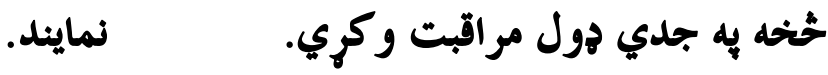

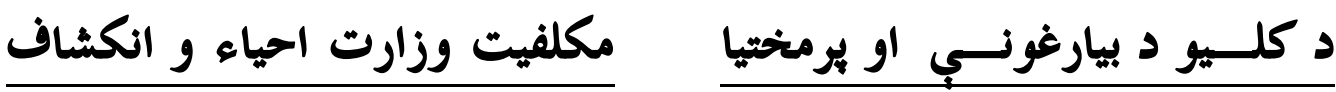

$$
\text { وزمارلمارت مكلفيتونه }
$$

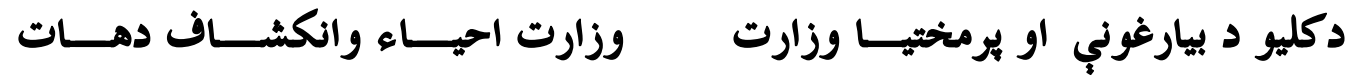

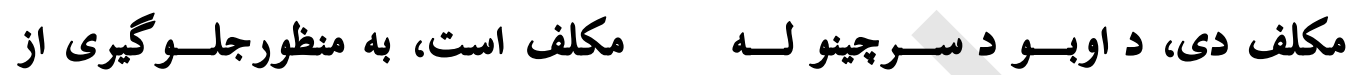

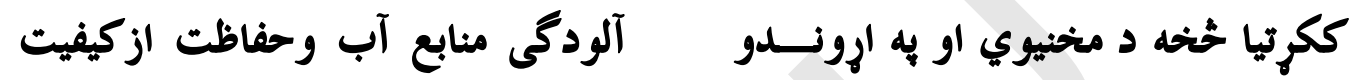

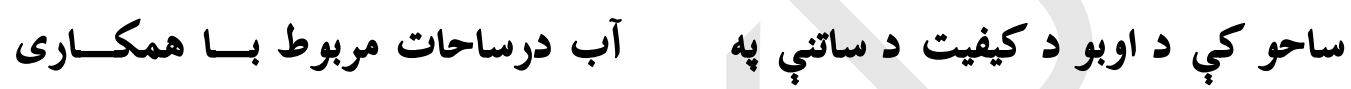

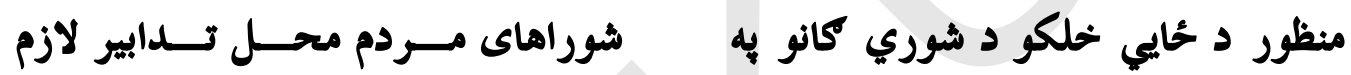

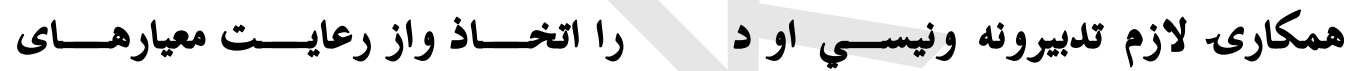

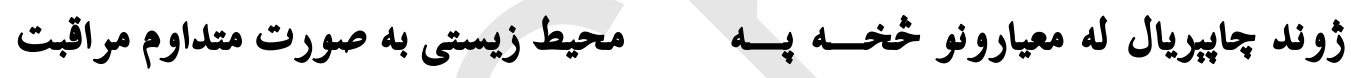
مثتداوم هول مراقبت وكري.

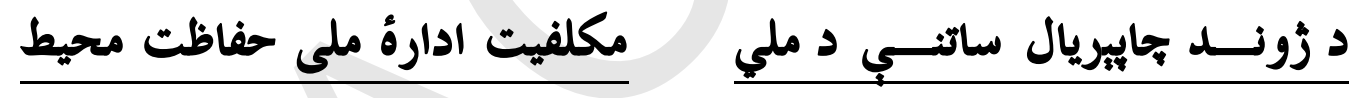
بنخخلسمه ماده:

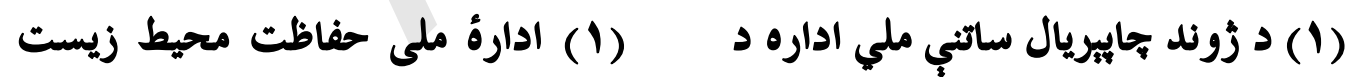

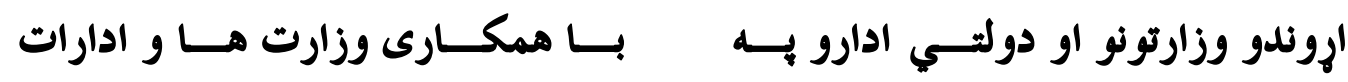

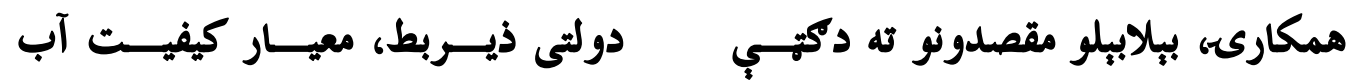

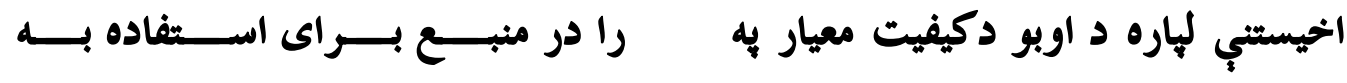

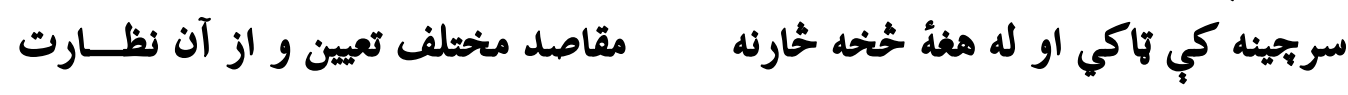
مى نمايد.

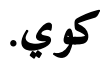


رسهي جريله

$\mid r q \Delta / r / r \Delta$

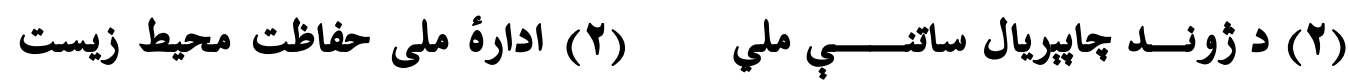

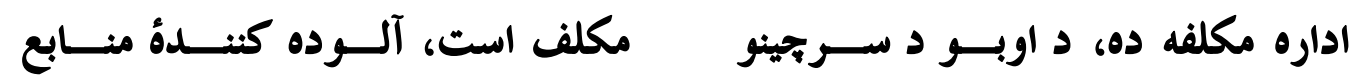

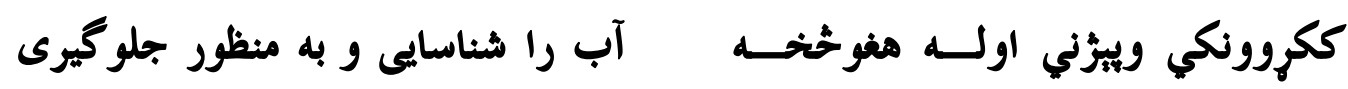
ذاذ

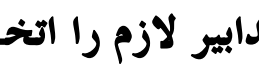

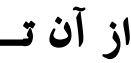

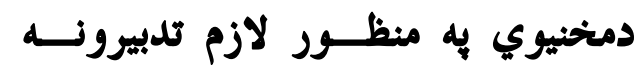

نمايد.

مكلفيت ادارة ملى ستندرد

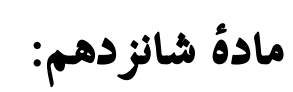

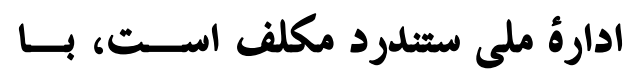
ممكارى ادارات ذيربط معيار و موارد اليكار استفادة مختلف از منابع آب را دماريين نموده و به دسترس مراجع متقاضى آن

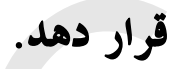

مكلفيت ادارة آمادگى مبارزه بـــا

$$
\begin{aligned}
& \text { حوادث مكاد } \\
& \text { مادة هفدهم: }
\end{aligned}
$$

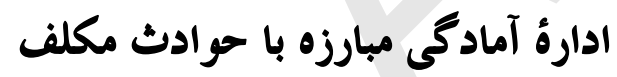

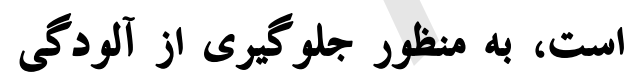

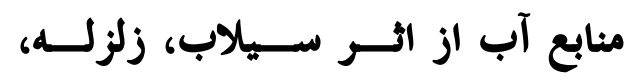

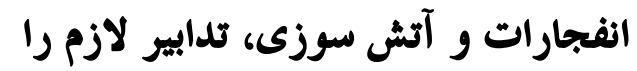

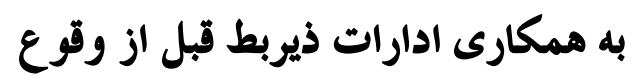
و بعد از آن اتخاذ نمايد.

$$
\text { ونيسي. }
$$

د ملي ستندرد د اداري مكلفيت

شيارسمه ماده:

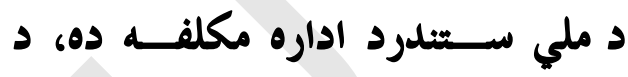

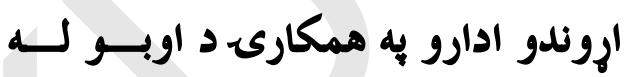

سرجينو خخخه د ببلا ببلي كتي اخيستبي

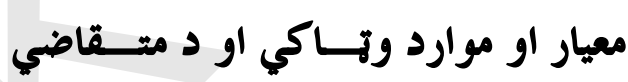
مراجعو به واك كي يجي وركري.

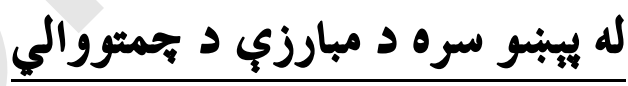
اوره اداري مكلفيت لسمه ماده: له يبنوسره د مبارزي د جحمتووالي اداره

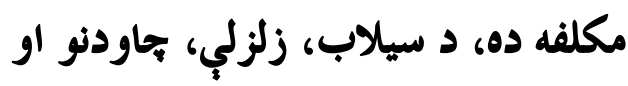

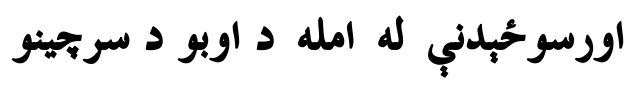

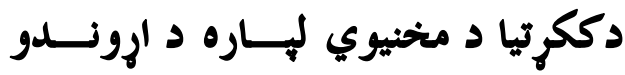

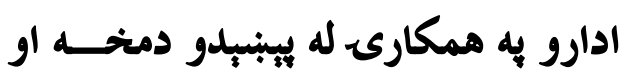
وروسته لازم تدبيرونه ونيسي. 


\section{مسلسل نمبر (IYIY) \\ رسهي جريله \\ مكلفيت استفاده كنندگان آب \\ مادة هجدهم: - مادئ \\ د اوبو د كتهه اخيستونكو مكلفيت \\ اتلسمه ماده:}

استفاده كندكان آب مكلف اند، جهت

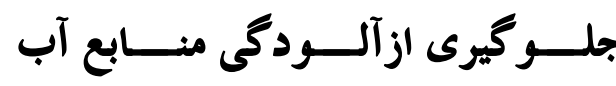

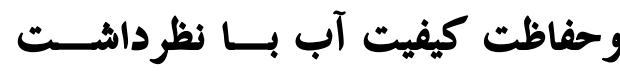
مقدار مصــرف ونحسوة اســفاده، تدابيرلازم را مطابق معيارهاى محسيط ونسي زيستى درســاحات مربــوط اتخـــاذ نمايند.

مكلفيت وزارت صحت عامه مادةُ نزدهم: مكيت وزات

وزارت صحت عامه مكلف است، بـــ

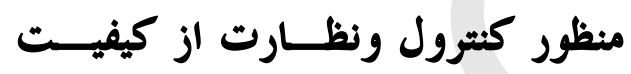

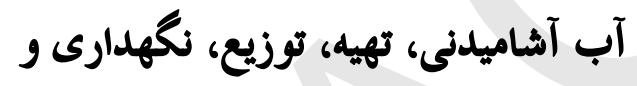

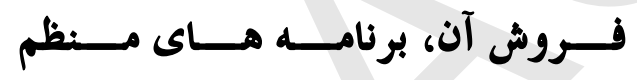
آكاهى دهى اضرار صـسى آلـودئى

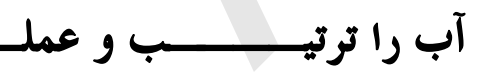
نمايد. مكلفيـــت ادارةُ راديوتلويزيــــــــ

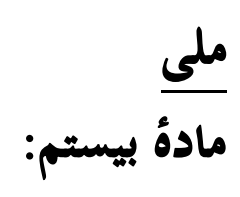
ادارة راديو تلويزيون ملى افغانســان
د اوبو كته اخيستونكي مكلف دي، د دادي

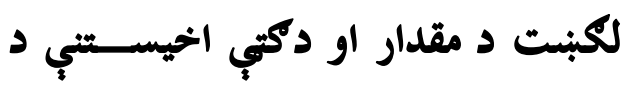

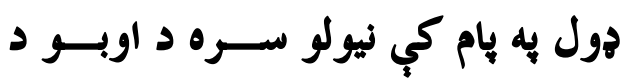

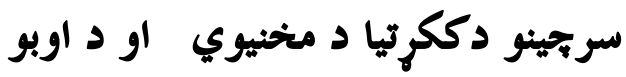

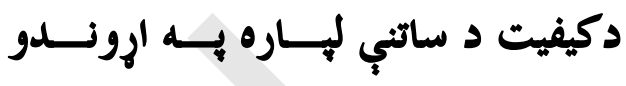
ساحوكي د زوند د جاييريال د معيارونو مطابق لازم تدييرونه ونيسي. د عامب روغنيا د وزارت مكلفيت نولسمه ماده:

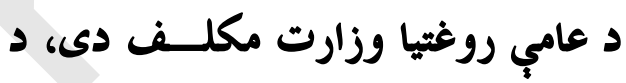

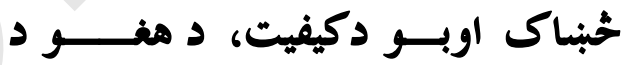

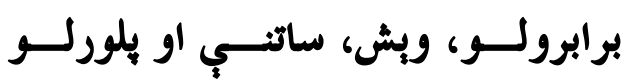

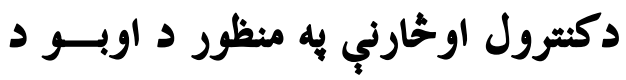

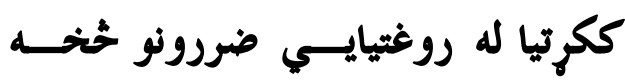
دخبرتيامنظمي برنامي ترتيب اوعملسي كري. مكلفيت ملـي راديو تلـــويزيون دادارب د افغانستان د ملي راديو تلويزيون اداره 


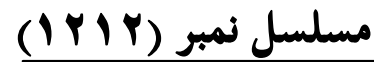 \\ ر سمي جريله}

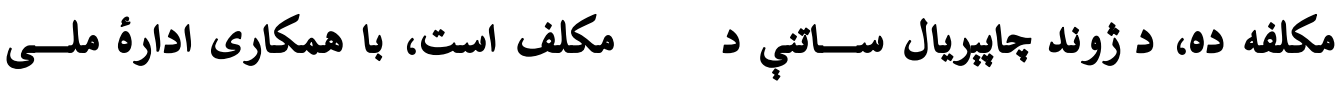

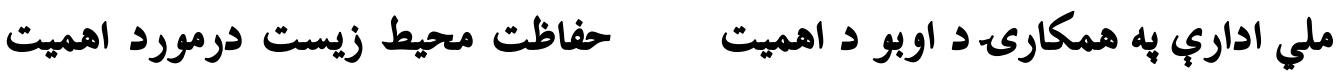

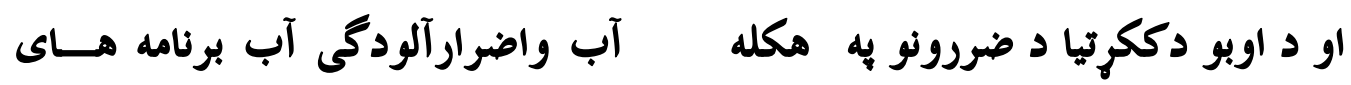

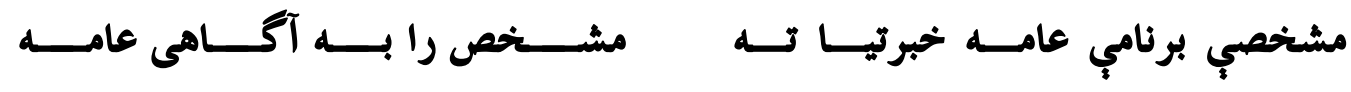
وروي.

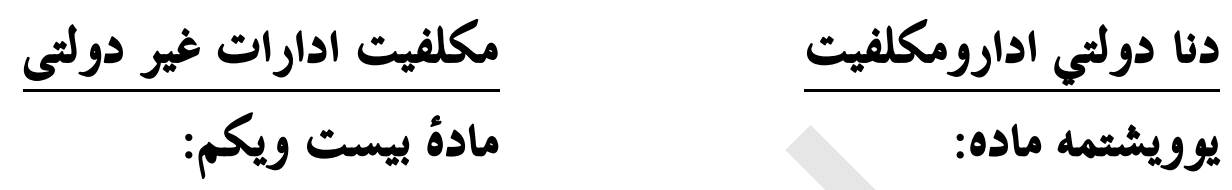

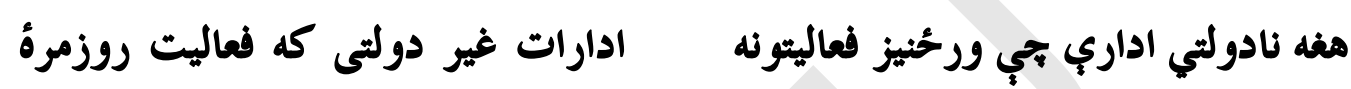

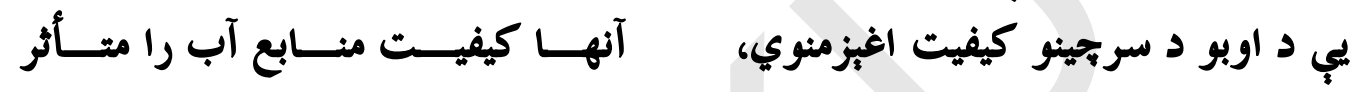

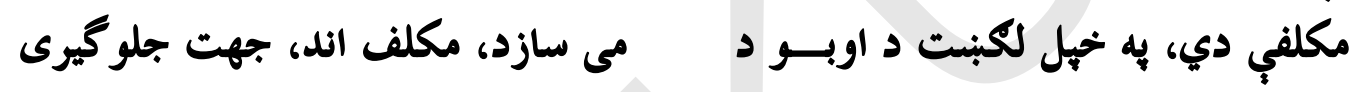

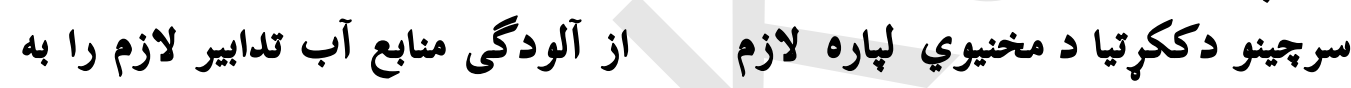
مصرف خود اتخاذ نمايند. مكلفيت عرضه كنندگان خدمات

$$
\text { فاضلاب }
$$$$
\text { تلديرونه ونيسي. }
$$

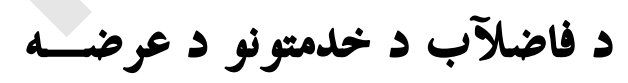
كوونكو مكلفيت دوه ويشتمه ماده:

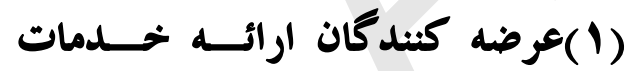

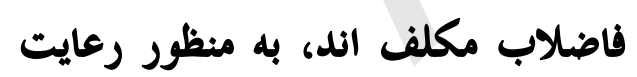

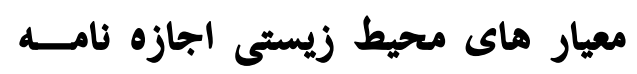
فعاليت را از ادارة ملى حفاظت محيط ابهازه نايط

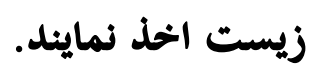

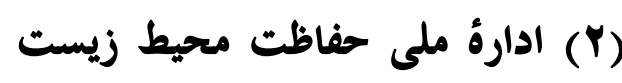

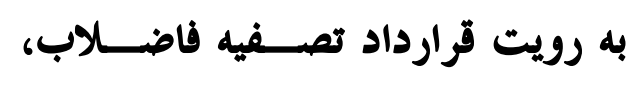

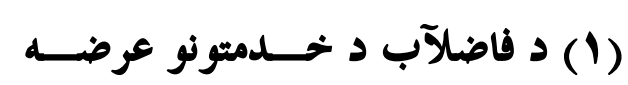
كورنكي مكلف دي، د دوند جاييريال

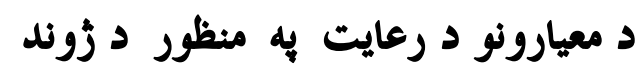

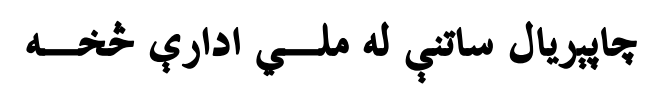
د فعاليت اجازه ليك واخلي.

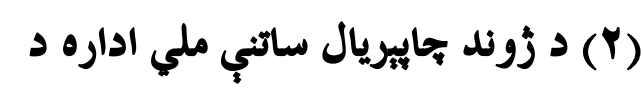

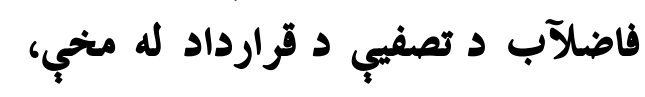




\section{مسلسل نمبر (I T Y \\ رسمي جريله}

اجازه نامه جمــع آورى، اسـتعمال و

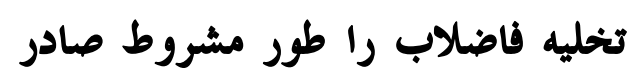
مى نمايد.

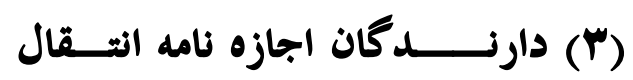

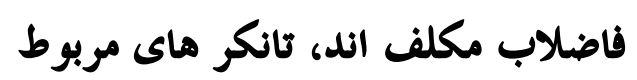

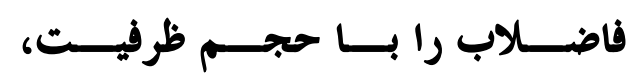

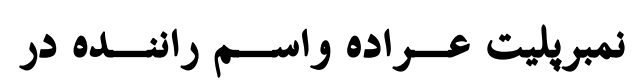
ادارة ملى حفاظت محيط زيست ثبت

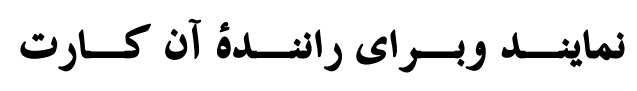

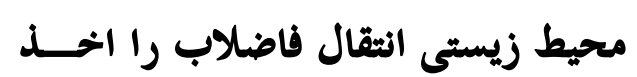
نمايند. مكلفيت توليد كنند گان فاضلاب منازل رهادة بيست وسئ

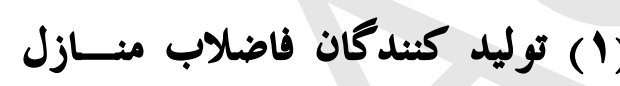

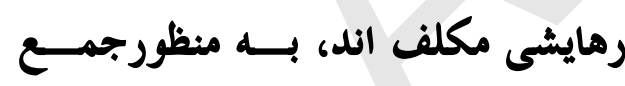

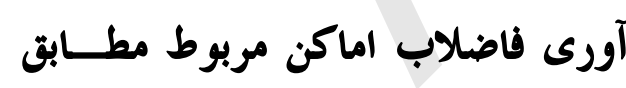

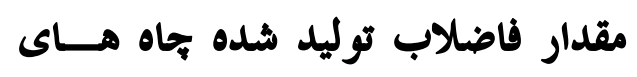
سيتيك معيارى احداث نمايند.

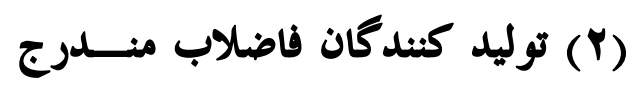

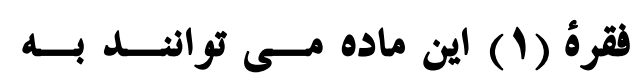
منظورانقال، تخليه وتصفيه فاضــلاب
به مشروط هول دفاضلآب د راتولولو،

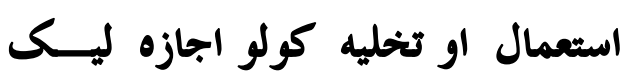
صادروي. ل

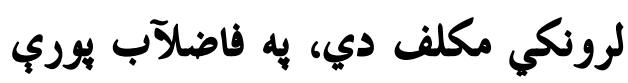

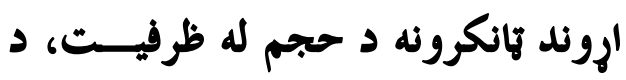

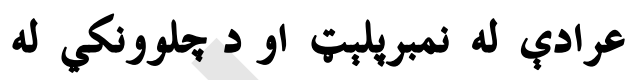
نوم سره د زوند جاييريال ساتني به ملي

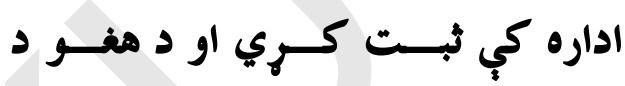
جلوونكو لياره د فاضلآب دلبودولو د دون زوند جاييريال كارت واخلي. د استوكني د كورونو د فاضلآب د د تورويدوونكو مكلفيت (1) د استوكني دكورونو د فاضــلآب توليدوونكي مكلف دي، د توليد شور

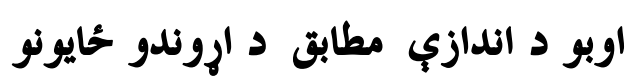

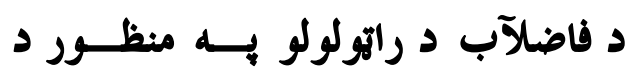
سيتيك معياري خاكاني احداث كري. (Y) دوي مادي به (1) فقره كي درج

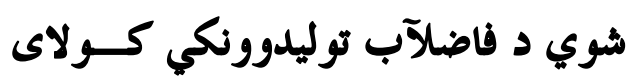

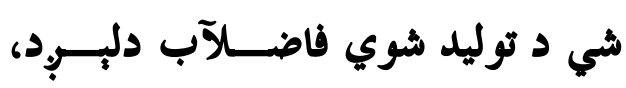




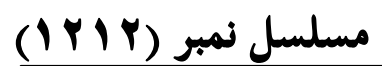 \\ رسهي جريله}

تخليب او تصفيب به منظور د فاضلآب توليد شده را با شركت مهـاى مجهاز

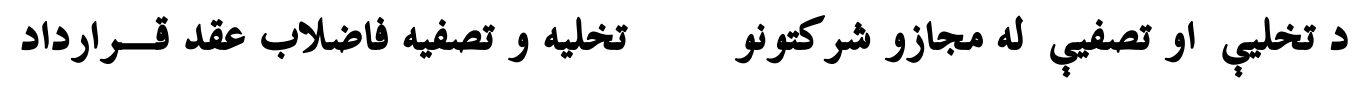
سره قرارداد وكري.

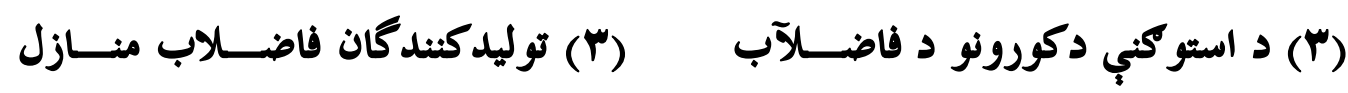

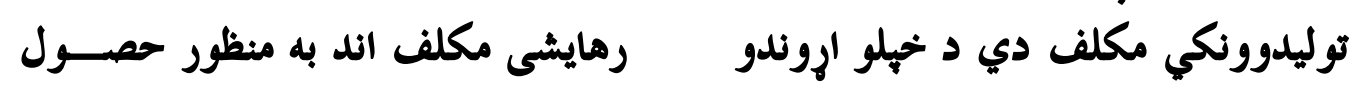

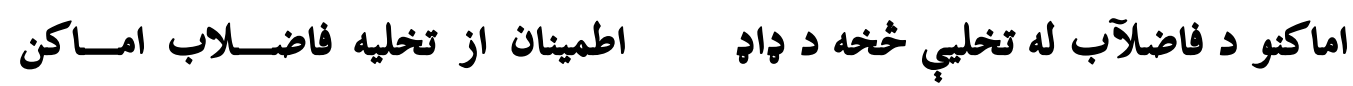

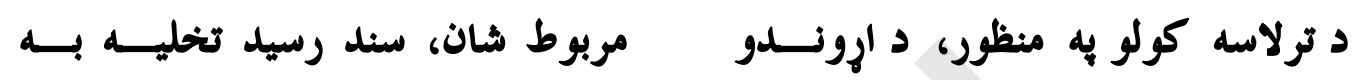

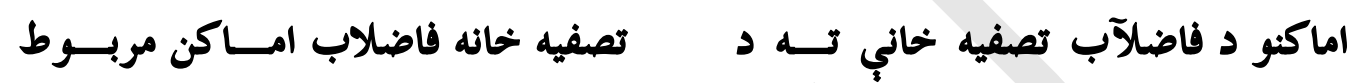

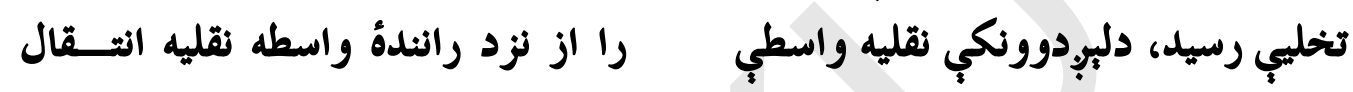

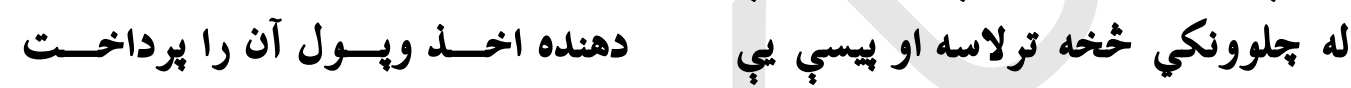
نمايند.

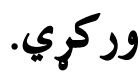

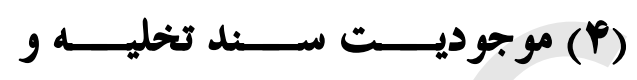
(\$) م د استوكني د كورونو د فاضلآب

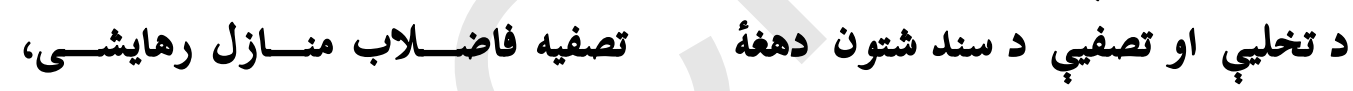

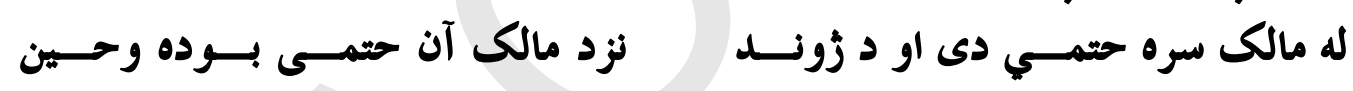

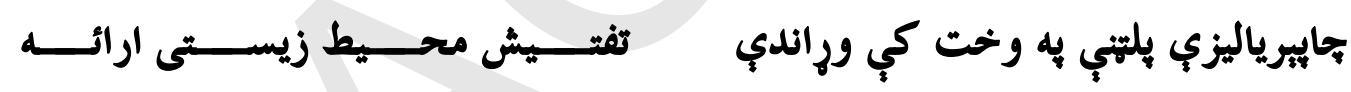

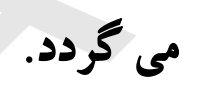

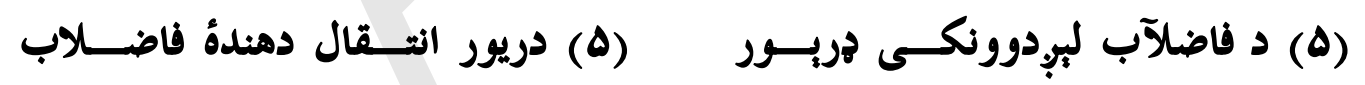

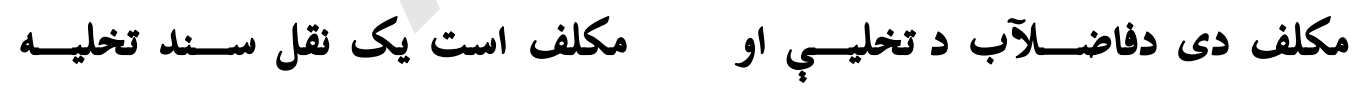

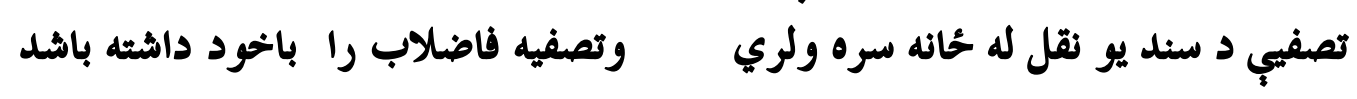

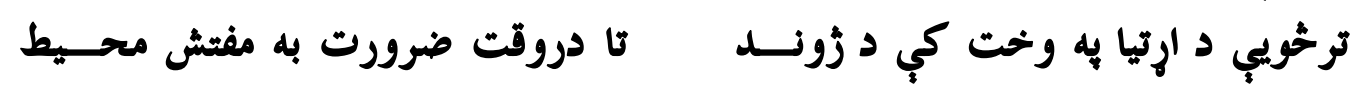
تحاييرياليز بلتونكي ته وراندي كري. 


\section{مسلسل نمبر (I M Y \\ ر سمي جريله \\ $\mid r q \Delta / r / r \Delta$}

مادمُ بيست آورى و ادهــــال فاضــلاب

د ادارو د فاضلآب راتولـــــــل اول

ادارات دولتى وغير دولى مى توانند،

دولتي او نادولتي اداري كولايى شي، د

به منظور جمع آورى فاضلاب مربوط، وعي دورئ

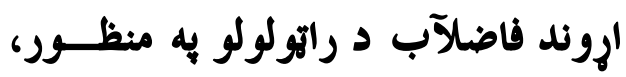

جاه هاى سيتيك معيارى را احداث ويا

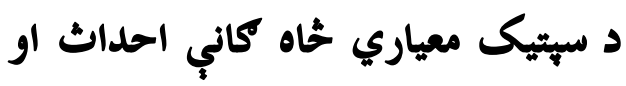

فاضلاب را به تصــفيه خحانــه مجـــــاز

يا فاضلآب هغو مجازو تصفيه خحانوتسـه

كه به اين منظور احداث شده انتــقال

جي به ممدب منظور احداث شوب دي

دم:d

وليجبدوي.

احداث تصفيه خانه

دتصفيه خانواحداث

مادة بيست وبنجم:

بنحُحه ويشتمه ماده:

مالكين شهرك هـــا، مجتمــع مـــاى

د بناركوتو مالكين، استوكنيزي مجتمع ولف ماده

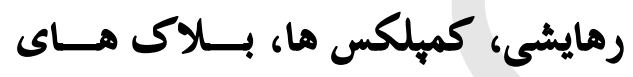

كاني، كميلكسونه، استوكنيزبلاكونه،

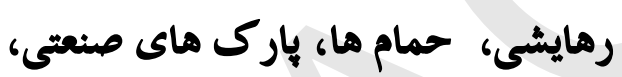
حمامونه، صنعتي هاركونه، روغتونونه،

شفاخانه ها، مراكز صحى و مؤسسات

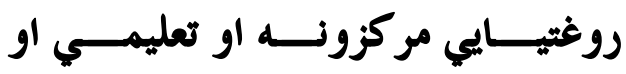
تعليمى و تحصيلى مكلف اند، به منظور تحصيلي مؤسسي مكلف دي، د اروند

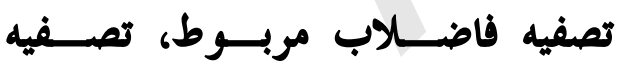
فاضلآب د تصفيب به منظور موضسـي مؤي خانه هاى موضعى را احداث يا آن را تهريه تصفيه نحاني جوري يايب هغو مجـــازو به تصفيه خحانه هاى مجاز كه به ايــن منظور احداث گرديده انتقال دهند.

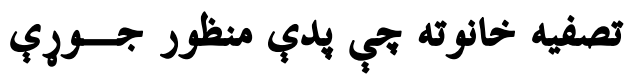
شوي دي ولببودوي. 


\section{مسلسل نمبر (I M Y (1) \\ رسهي جريله \\ $\mid r q \Delta / r / r \Delta$}

وصل جاه هاى سيتيك فاضــلاب

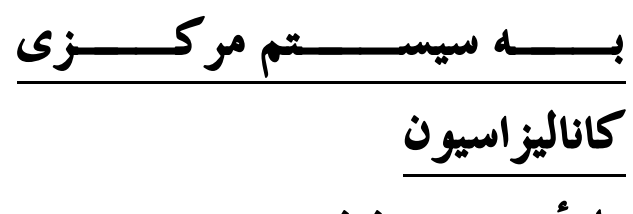

مادة بيست وششم:

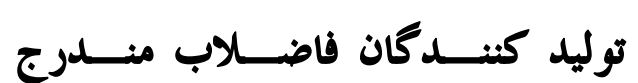

مواد بيست وجهارم، بيست وينجم و

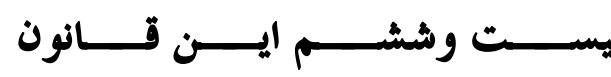

مى توانلد درصورت ايجـــاد سيســمتم

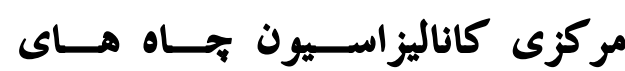

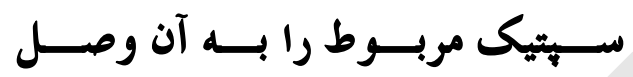

نمايند.

مكلفيت انجمن هـــاى اســـفاده

$$
\begin{aligned}
& \text { كندئان آب } \\
& \text { مادة بيست وهفتم: }
\end{aligned}
$$

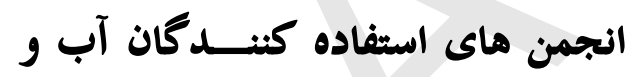

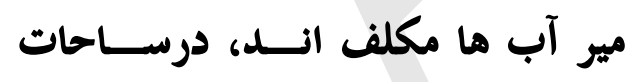

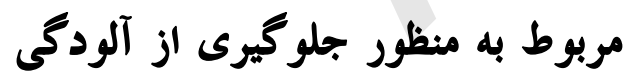
منابع آب، مردم محل را آكـــاهى داده مئل وبراى حفاظت كيفيت آب با ادارات ذيربط همكــارى و ممــامنكى لازم نمايند.
دكاناليزاسيون له مركزي سيســم

سره د فاضلآب دسيتيك ثخاه كانو

وصل

شيتوبِويشتمه ماده:

ددغهُ قانون به خحليريشتمه، بنحُه ويشتمه مادهة

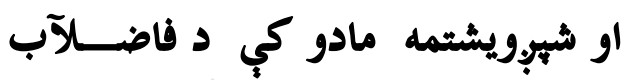

درج شوي توليدوونكي كولاى شي د داصي

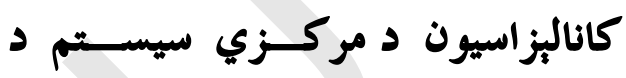

رامنحُته كجدو به صورت كي د سيتيك

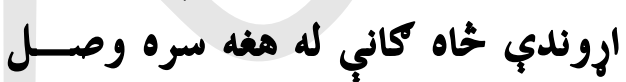

كري.

له اوبو حخخه د كته اخيســتونكو

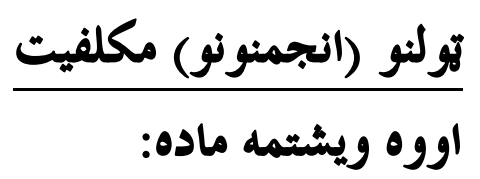

له اوبو خخخه كته اخيستونكي تولني او

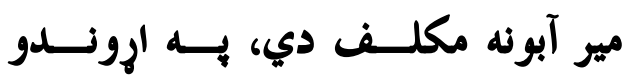

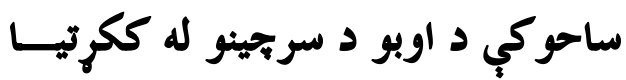

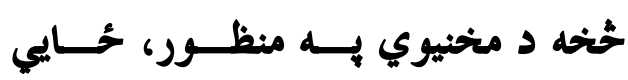

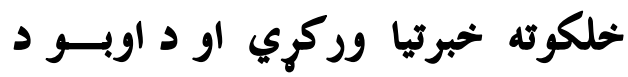
كيفيت د ساتني لهاره له اروندو ادارو سره لازمه همكاري او همغبوي وكري. 
رسمي جريله

$\mid r q \Delta / r / r \Delta$

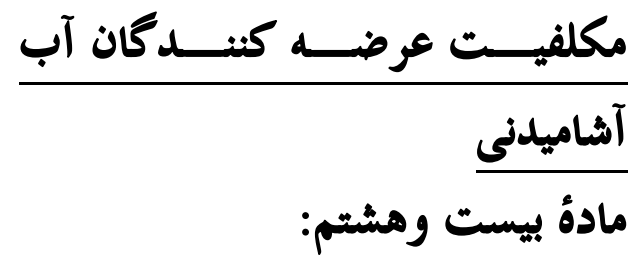

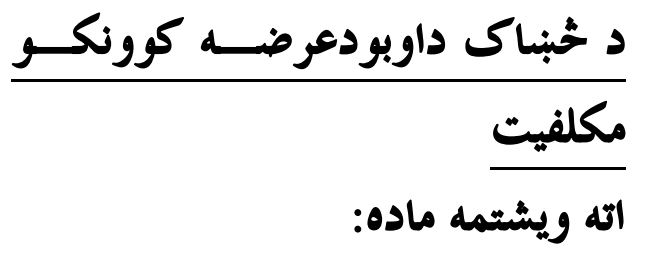

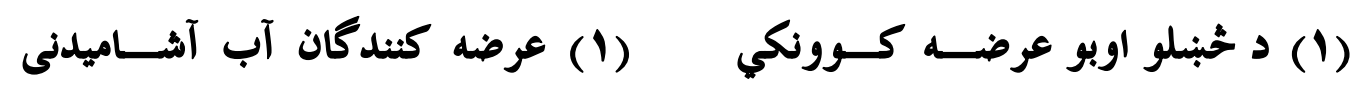

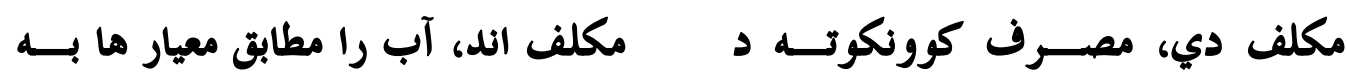

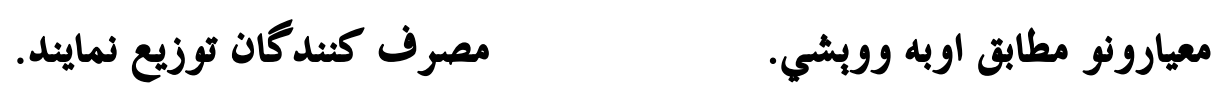

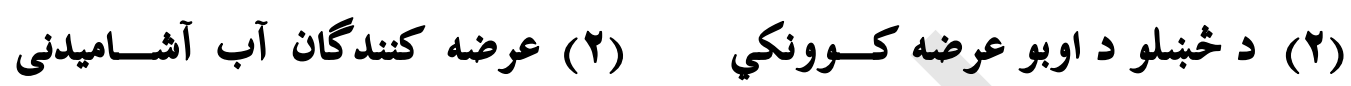

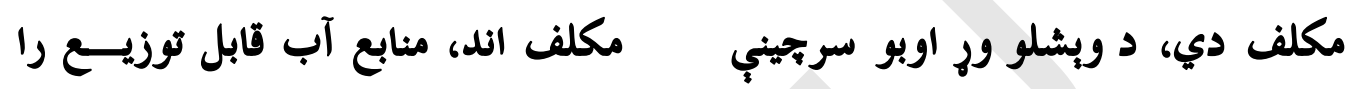

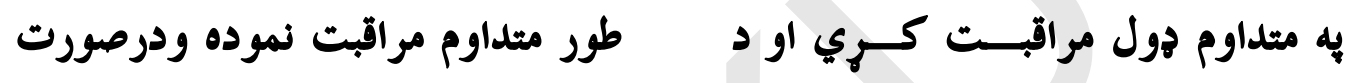

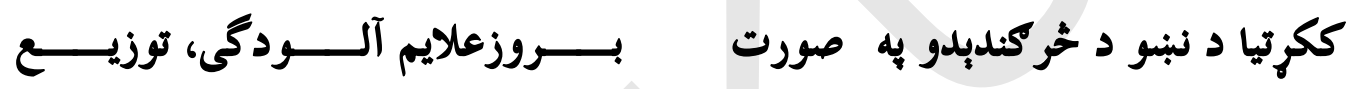

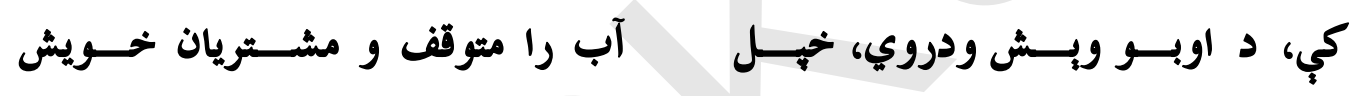

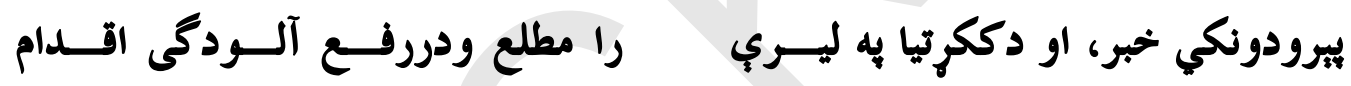
نمايند.

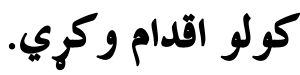

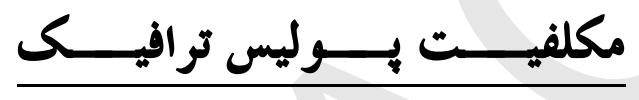
مادةُ بيست ونهم:

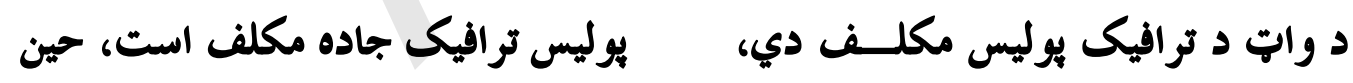

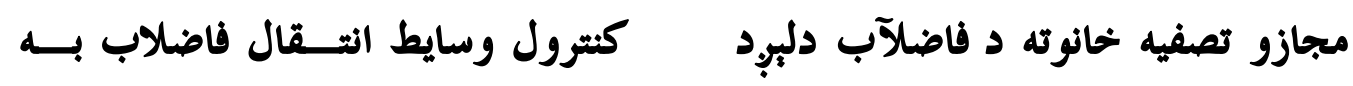

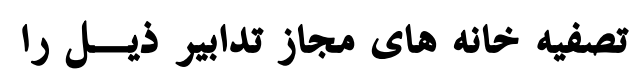

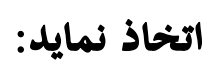

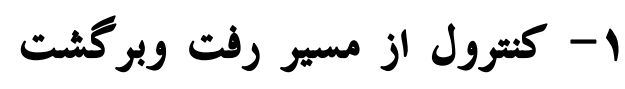
تعيين شدة تانكرماى فاضلاب.

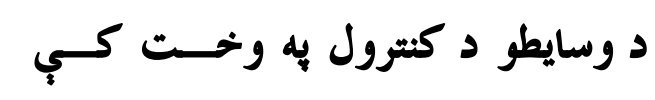

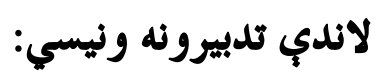
1- 1 دفاضلآب د ديانكرونو د نتى راتئى

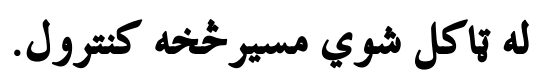




\section{رسمي جريده}

$\mid r q \Delta / r / r \Delta$

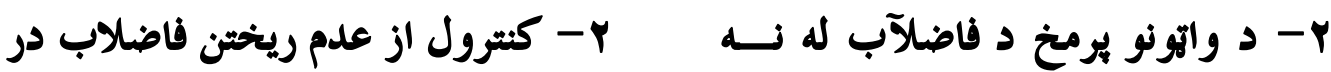

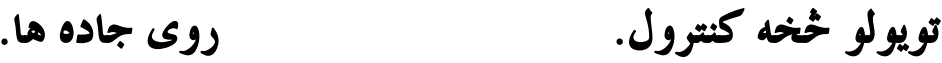

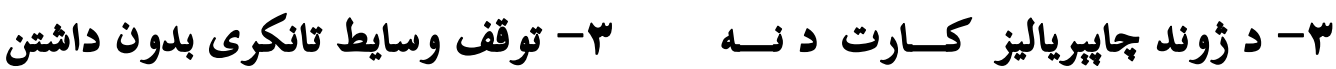

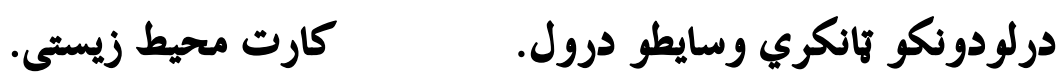

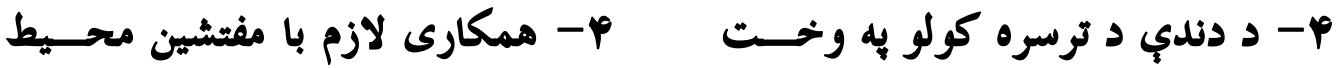

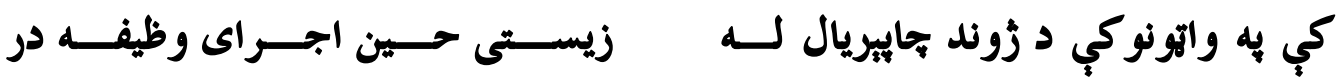

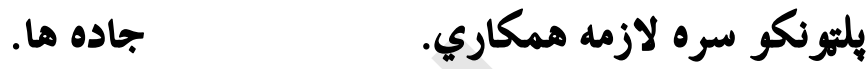

د فاضــلآب د تصــفـيه خــــانو د مكلفيت مسئولين تصفيه خحانه هاى

$$
\text { مسئولينو مكلفيت }
$$

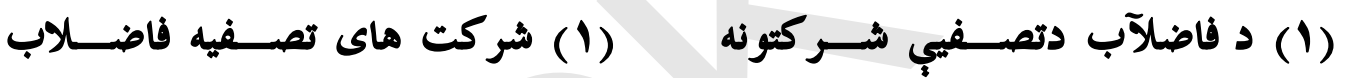

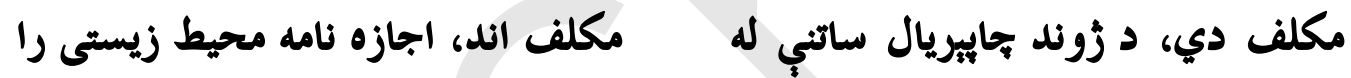

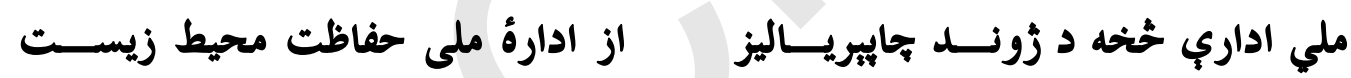

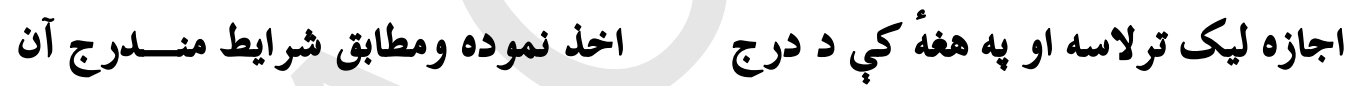
شوو شرايطو مطابق عمل وكري.

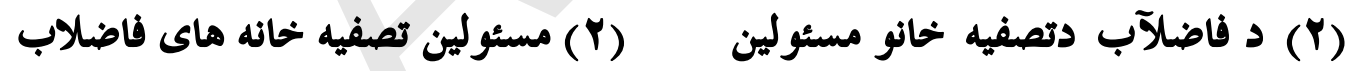

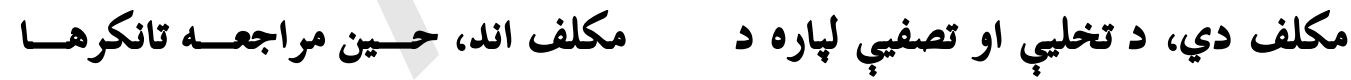

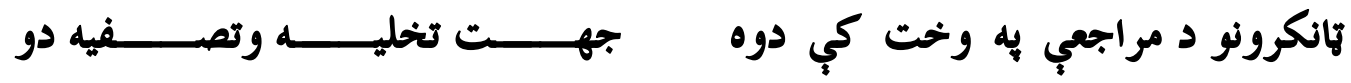

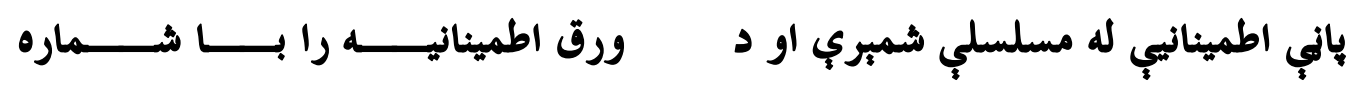

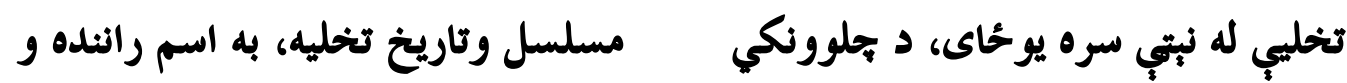

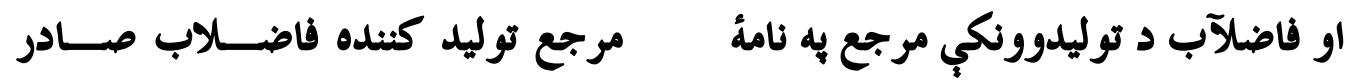

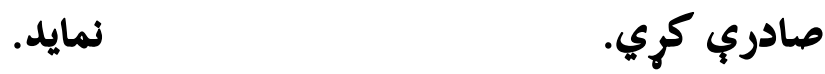




\section{رسهي جريده}

$\mid r q \Delta / r / r \Delta$

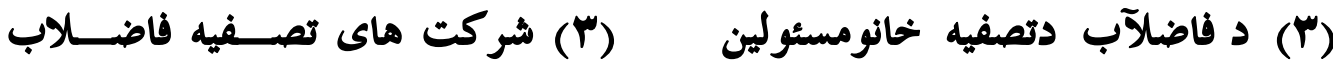

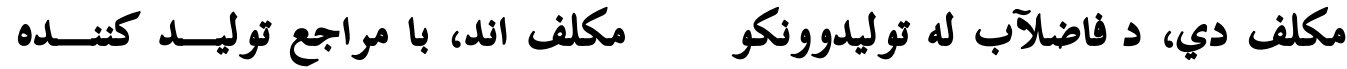

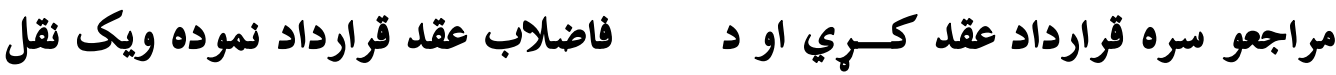

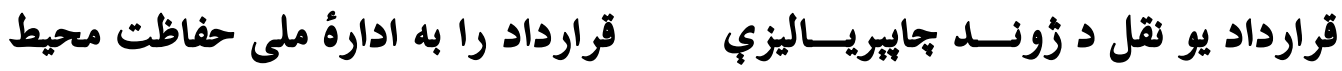

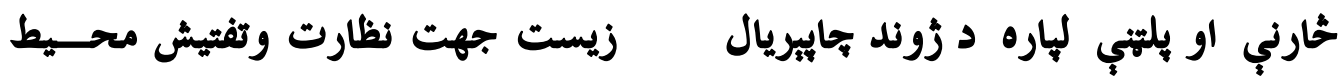

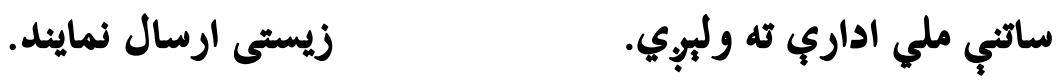

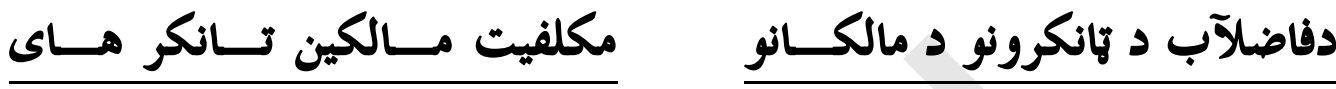
يودير شملفيت ماده:

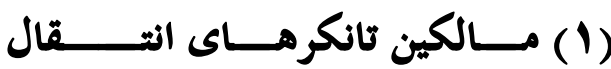
(1) دفاضلآب دوتانكرونومالكان مكلف هاتف فاضلاب مكلف اند، خود را دريكى از

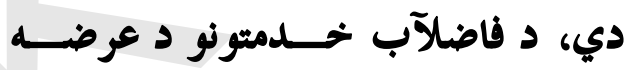

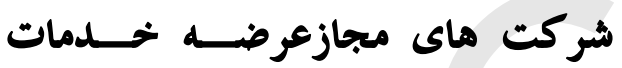
كوونكو مجازو شركتونو به يوهُ كـــي فاضلاب ثبت نموده وكارت انتـقال

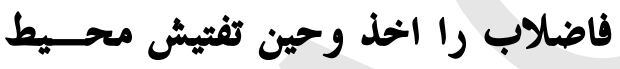

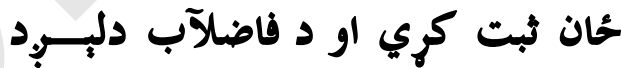
كارت واخلي او د زؤند جاييريــاليزي زيستى ارائه نمايند. بلتني به وخت كي يب وراندي كري. درصورت عدم موجوديت شركت هاى ماري د فاضلآب خدمتونو د عرضه كوونكو مجازعرضه خدمات فاضلاب، مالكين

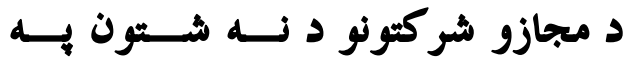
تانكرهاى انتــال فاضلاب مكلف اند، ماتهات

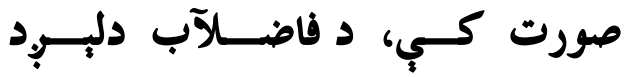
تانكر هاى خود را درادارة ملى حفاظت

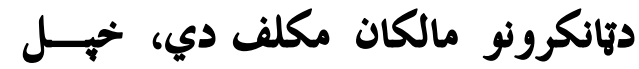

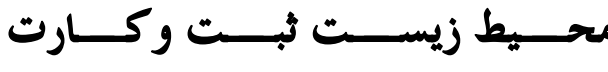
تانكرونه د زؤند جايبريال ساتني به ملي

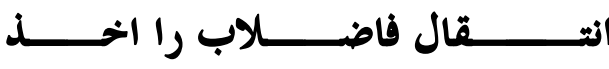

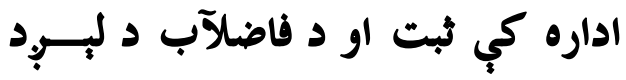
نمايند.

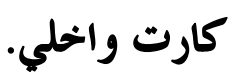




\section{رسهي جريده}

$1 r q \Delta / r / r \Delta$

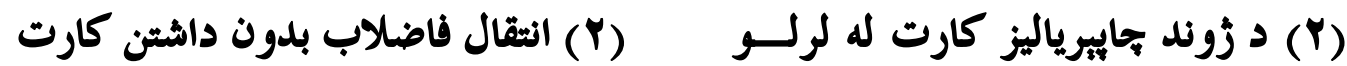

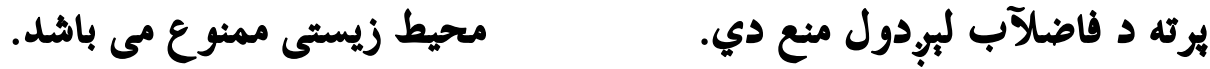

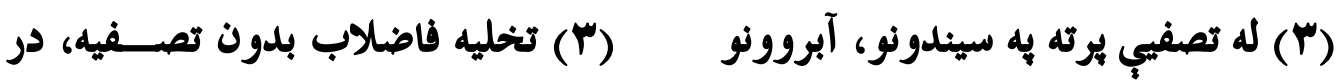

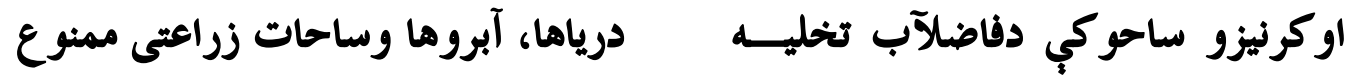

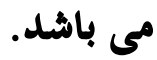

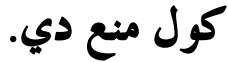

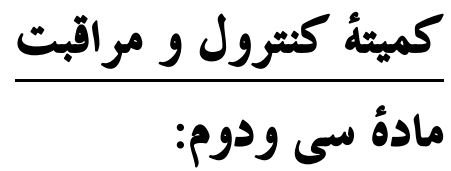

د كنترول اومراقبت كميزه

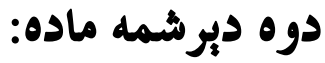

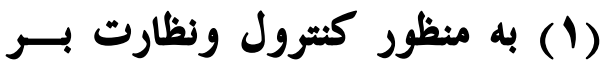

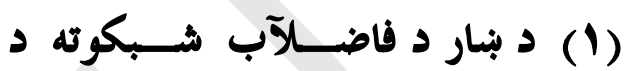

تخليه فاضلاب به شبكه هاى فاضلاب

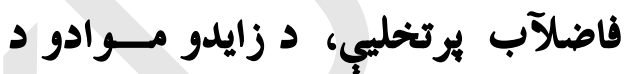

شهر، جمع آورى، حمل ونقل ودفــــ

راتولولو، حمل اونقل اودفع دخـــارني

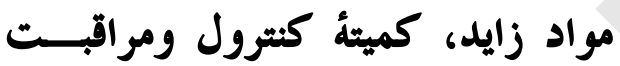

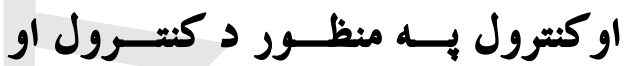

درمركز به ييشنهاد رئيس عمومى ادارة

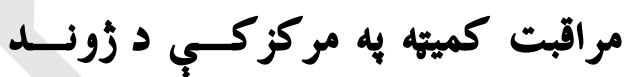

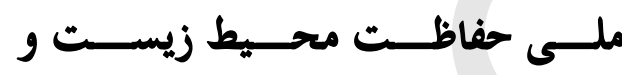
جاييريال ساتني د ملي اداري د عمومي هي هري

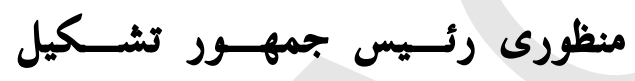
رئيس هيه ورانديز او د جمهو ررئيس به ديه مى گردد. منظورى تشكيليوي.

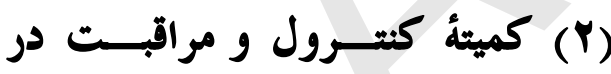
(Y) به ولايتونوكي دكنترول اومراقبت

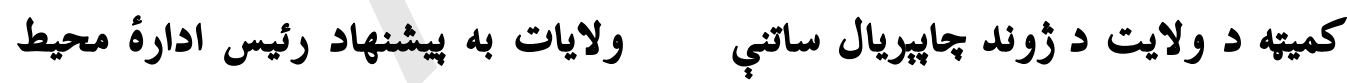

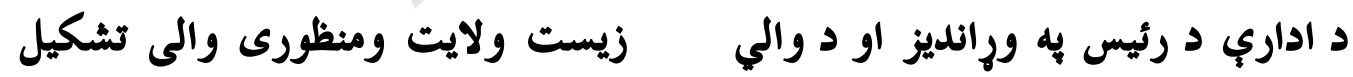
مى كردد. به منظورى تشكيليوب.

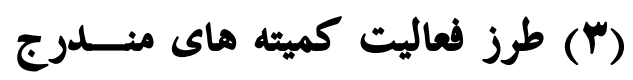

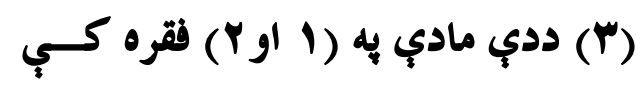

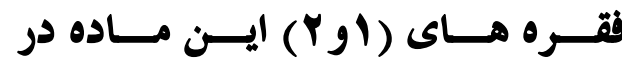

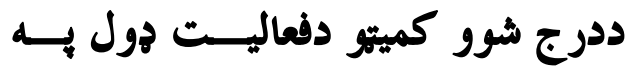

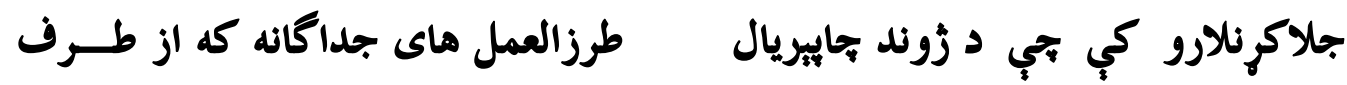




\section{رسمي جريده}

مسلسل نمبر (I Y Y (Y) $\mid r q \Delta / r / r \Delta$

اداره ملى حفاظت محيط زيست ترتيب ساتني دملي اداري له خــــوا ترتيـبـ

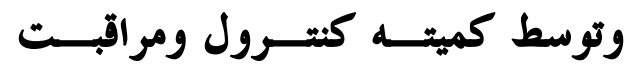

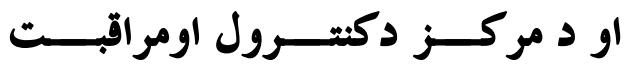

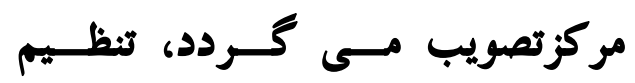

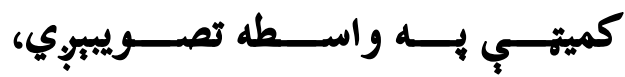

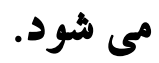

فصل تحهارم

حملورم فصل

احكام نهايق وروستني حكمونه

تخلف وجبران سمساره وسوم: درغي ديرشمه ماده: اودخساري جبر ان

الـــخاص حقيقــى وحكمــى كـــه

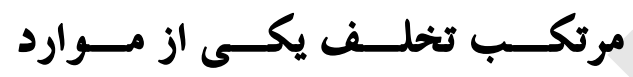
هغه حقيقي اوحكمي اشخاص هي بدي مقرره كي له درج شوو مواردو خحخه له له

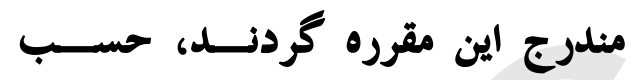

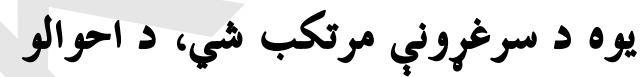

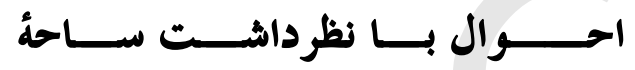

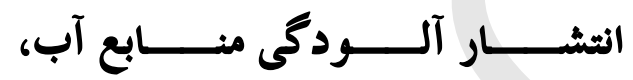

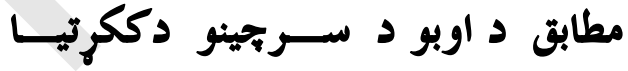

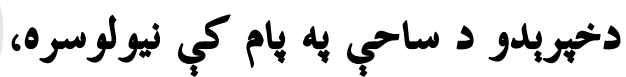

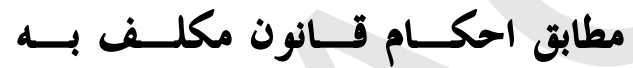

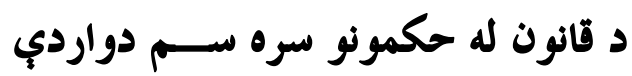

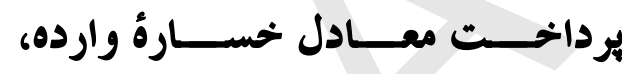

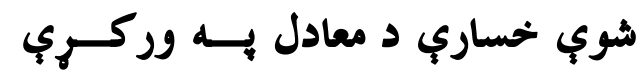
مى باشند. مكلف دي.

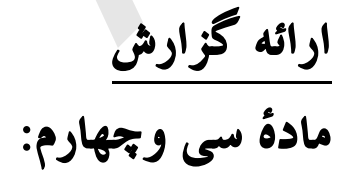
دريوت وراندي كول خملوردبرشمه ماده:

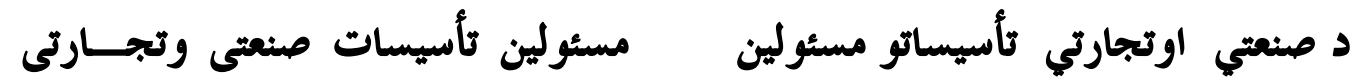

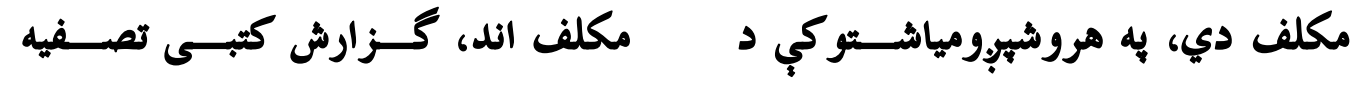

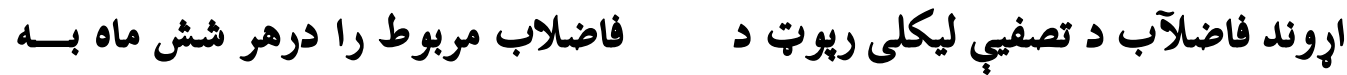

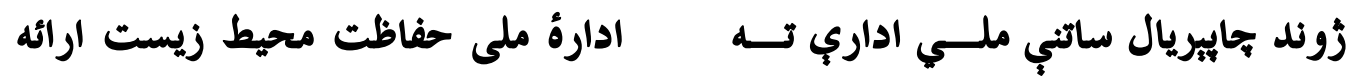




\section{مسلسل نمبر (IYIY) \\ رسهي جريله \\ $\mid r q \Delta / r / r \Delta$ \\ نمايند. \\ وراندي كري.

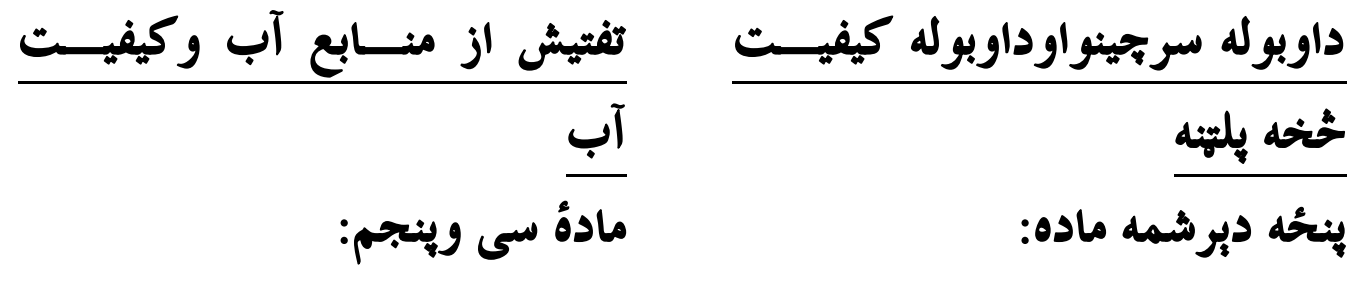

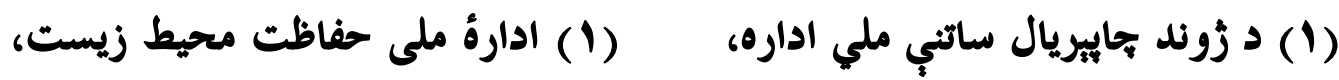

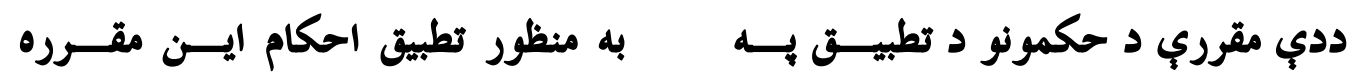

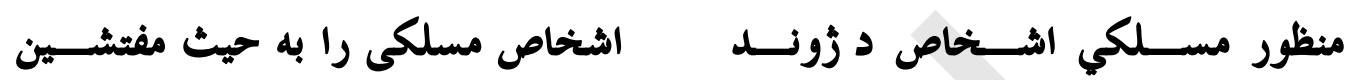

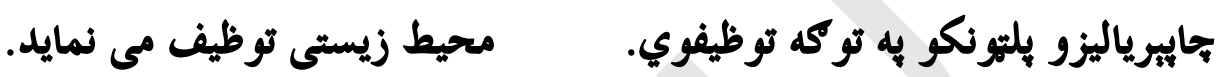

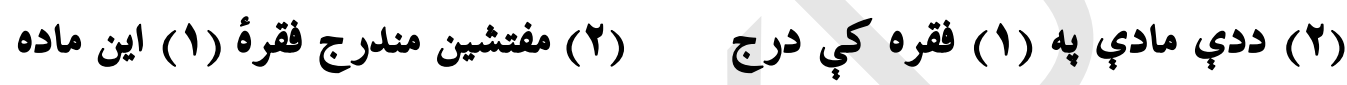

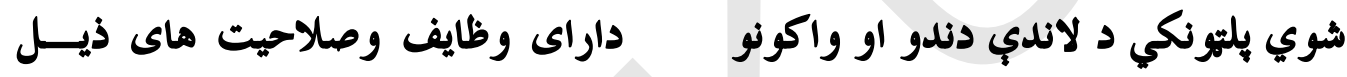

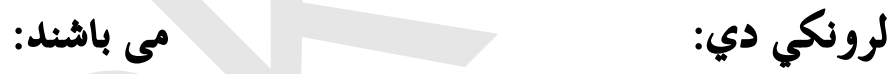

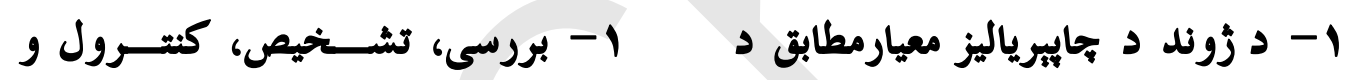

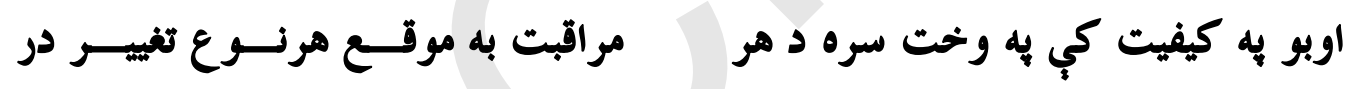

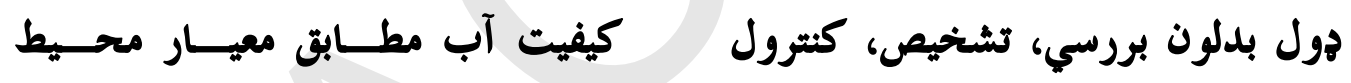

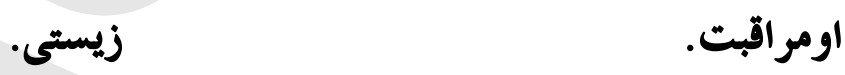

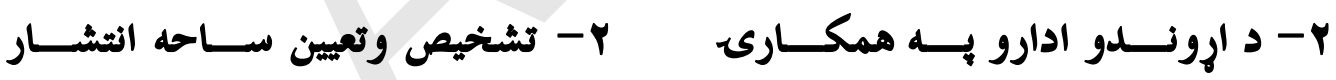

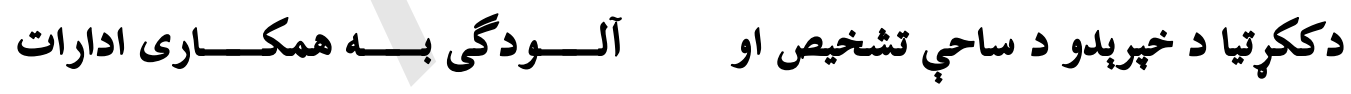
ذيربط.

تواكل.

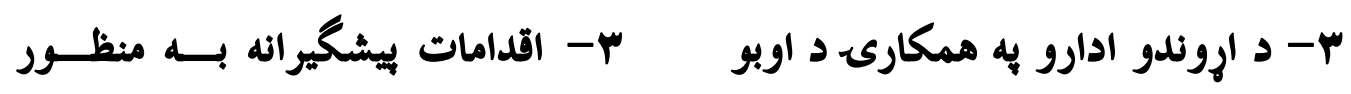

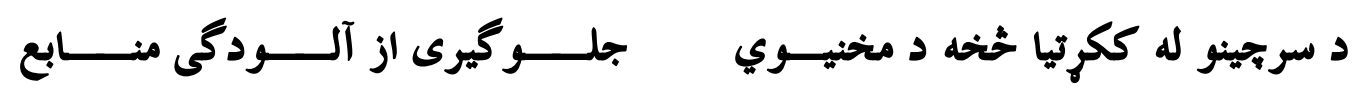

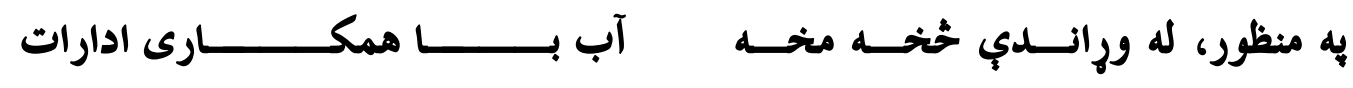

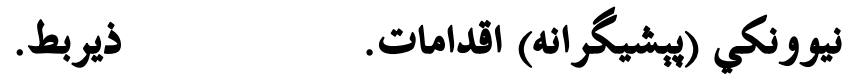




\section{رسمي جريده}

$\mid r q \Delta / r / r \Delta$

†- بررسى و نظارت از تطبيق شرايط

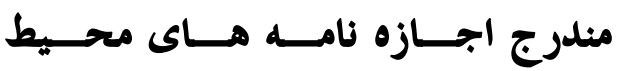

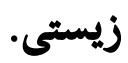

†- د زوند بــه جايريــاليزو اجــازه ليكونوكي د درج شوو شرايطو له تطبيق

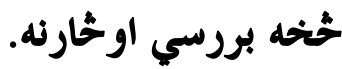

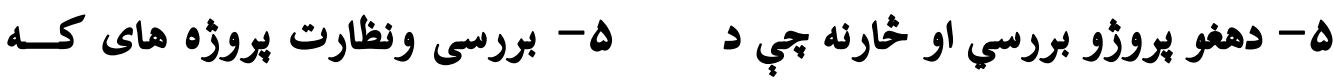
منابع آب را مثأثر مى سازند. اوبو سرجيني اغيزمنوي.

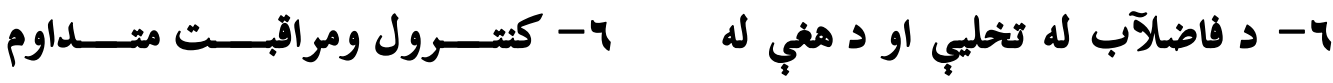

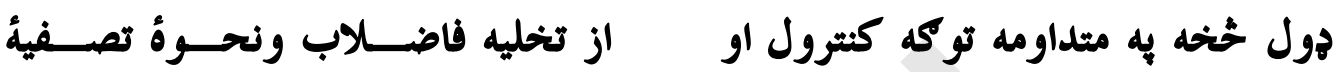
آن.

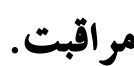

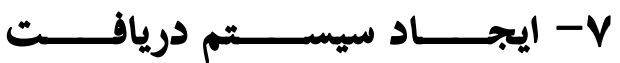

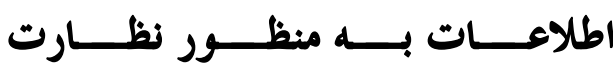

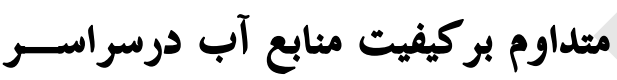

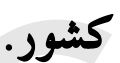
(זّ) وزارت ها وادارات دولتى وغيـــر

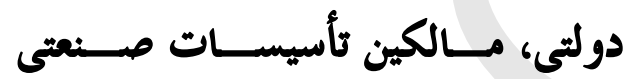
وتجارتى كه منابع آب را مورد استفاده قرارمى دهند، مكلف اند، تســـهيلات

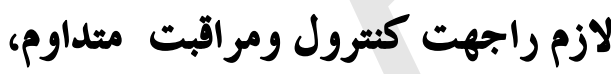

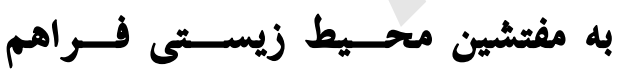
نمايند. مادة سى وششع لوايح وطرزالعمل ها:

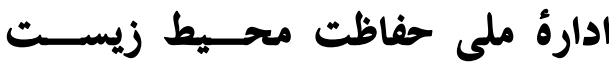

V- به تول هيوادكي د اوبو د سرجينو

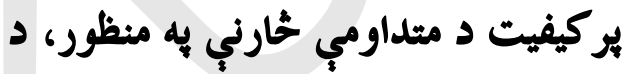

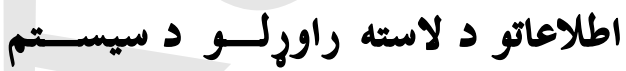

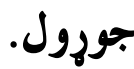
(ז) هغه وزارتونه، دولتي او نــادولتي اداري او د صنعتي او تجارتي تأسيساتو

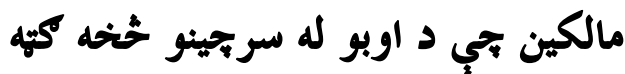
اخلي، مكلف دي، د زوزند جاييرياليزو

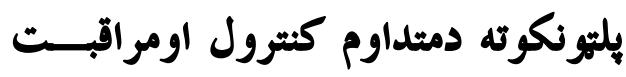

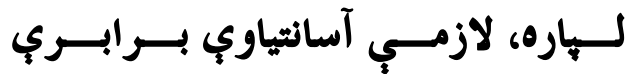
كري.

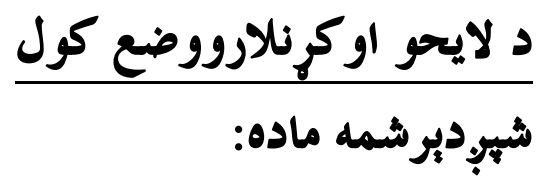
د زوند جاييريال ساتني ملــي اداره د د ماده 


$$
\begin{aligned}
& \text { 1 rqه/r/rd }
\end{aligned}
$$

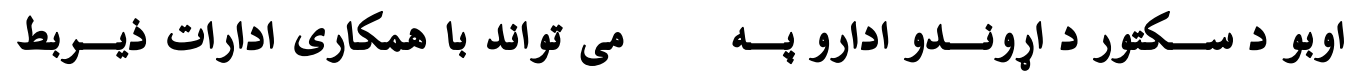

$$
\begin{aligned}
& \text { همكارى كولاى شي ددي مقــرري د سكتور آب به منظور تطبيت بهتر احكام }
\end{aligned}
$$

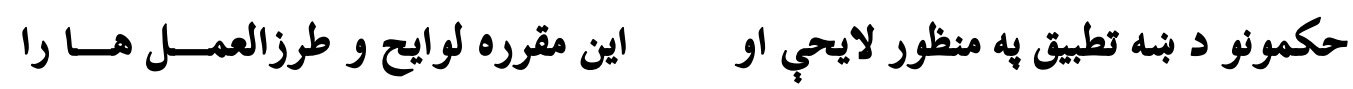

$$
\begin{aligned}
& \text { وضع نمايد. } \\
& \text { كرنلاري وضع كري. } \\
& \text { انفاذ } \\
& \text { مادةُ سى و هفتم: }
\end{aligned}
$$

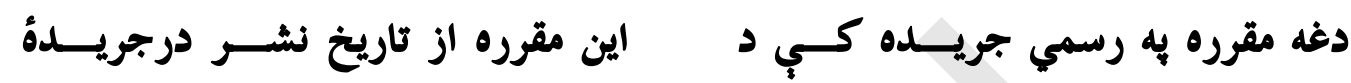

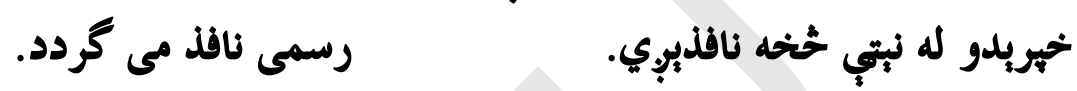




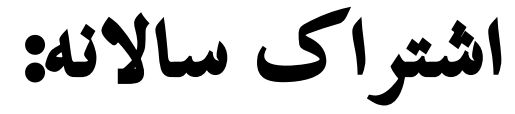

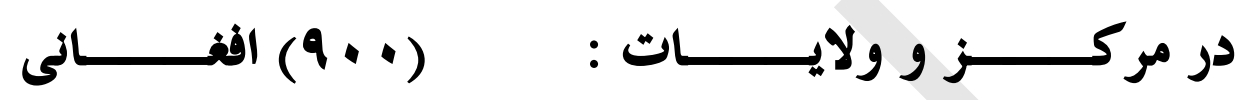

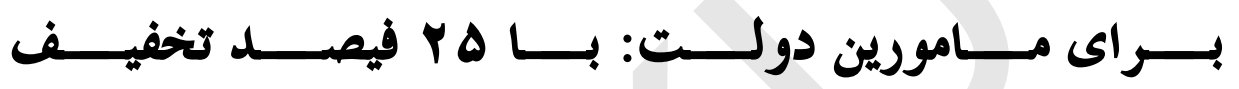

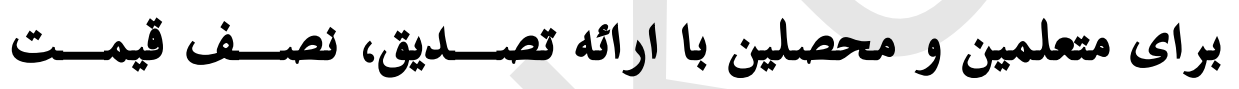

براى كتاب فروشى ما با ـ ا ف فيصد تخفيف از قيمت روى جلد

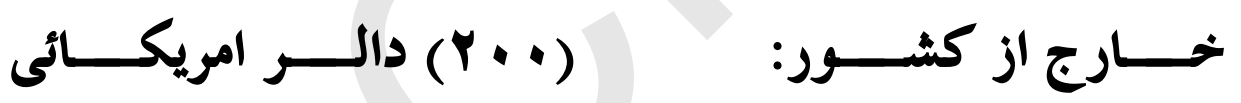




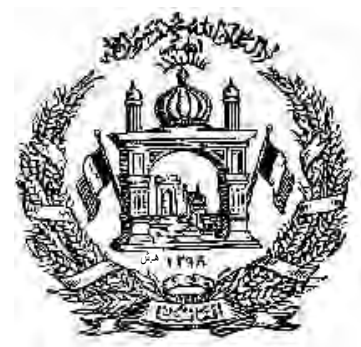

\section{ISLAMIC REPUBLIC \\ OF}

AFGHANISTAN

MINISTRY OF JUSTICE

\section{OFFICIAL GAZETTE}

\section{Regulation on Water Quality Control and Maintenance}

Date: $14^{\text {th }}$ May .2016

ISSUE NO :(1212) 